\title{
Gene Expression Changes in the Course of Neural Progenitor Cell Differentiation
}

\author{
Ulf Gurok, ${ }^{1,2}$ Christine Steinhoff, ${ }^{1}$ Bettina Lipkowitz, ${ }^{1}$ H.-Hilger Ropers, ${ }^{1}$ Constance Scharff, ${ }^{1}$ and Ulrike A. Nuber ${ }^{1}$ \\ ${ }^{1}$ Max Planck Institute for Molecular Genetics, 14195 Berlin, Germany, and ${ }^{2}$ Freie Universität Berlin, Fachbereich Biologie, Chemie, Pharmazie, 14195 Berlin, \\ Germany
}

The molecular changes underlying neural progenitor differentiation are essentially unknown. We applied cDNA microarrays with 13,627 clones to measure dynamic gene expression changes during the in vitro differentiation of neural progenitor cells that were isolated from the subventricular zone of postnatal day 7 mice and grown in vitro as neurospheres. In two experimental series in which we withdrew epidermal growth factor and added the neurotrophins Neurotrophin-4 or BDNF, four time points were investigated: undifferentiated cells grown as neurospheres, and cells 24, 48, and $96 \mathrm{hr}$ after differentiation. Expression changes of selected genes were confirmed by semiquantitative RT-PCR. Ten different groups of gene expression dynamics obtained by cluster analysis are described. To correlate selected gene expression changes to the localization of respective proteins, we performed immunostainings of cultured neurospheres and of brain sections from adult mice. Our results provide new insights into the genetic program of neural progenitor differentiation and give strong hints to as yet unknown cellular communications within the adult subventricular zone stem cell niche.

Key words: development; differentiation; hybridization; ventricle; stem cell; microarray; subventricular zone; rostral migratory stream; neurosphere

\section{Introduction}

Adult neural progenitor/stem cells in rodents and primates are well characterized in two brain regions: the subventricular zone (SVZ) of the lateral ventricles and the subgranular cell layer of the hippocampal dentate gyrus (McKay, 1997; Eriksson et al., 1998; Kornack and Rakic, 1999; Gage, 2000; Temple 2001; AlvarezBuylla et al., 2002; Sanai et al., 2004). Stem cells in the adult SVZ are self-renewing and give rise to neurons that incorporate as interneurons into the olfactory bulb. Within the rodent SVZ, four major cell types have been described: ependymal cells lining the lateral ventricle, astrocytes (type B cells), and rapidly dividing transit-amplifying type $\mathrm{C}$ cells that generate neuroblasts (type A cells) (Doetsch et al., 1997). SVZ neuroblasts migrate as chains in the rostral migratory stream (RMS) to the olfactory bulb through tunnels formed by type B astrocytes (Lois et al., 1996; Peretto et al., 1997; Wichterle et al., 1997). The identity of the SVZ stem cell has been controversial. Originally proposed to correspond to a rare population of relatively quiescent cells (Morshead et al., 1994), ciliated ependymal cells were later suggested to represent the SVZ stem cell (Johansson et al., 1999). Findings of other groups, however, indicate that SVZ astrocytes (type B cells) are neural stem cells (Chiasson et al., 1999; Doetsch et al., 1999a,b; Laywell et al., 2000; Capela and Temple, 2002).

Received Dec. 2, 2003; revised April 26, 2004; accepted May 14, 2004

This work was supported by Deutsche Forschungsgemeinschaft Grant SFB577. We thank Andrew Fanous for technical assistance and Isabelle Caille for support in establishing neurosphere cultures.

Correspondence should be addressed to Ulrike A. Nuber, Max Planck Institute for Molecular Genetics, Human Molecular Genetics, Ihnestrasse 73, Berlin 14195, Germany. E-mail: nuber@molgen.mpg.de. DOI:10.1523/JNEUROSCI.0809-04.2004

Copyright $\odot 2004$ Society for Neuroscience $\quad$ 0270-6474/04/245982-21\$15.00/0
Cultured cells from the adult subventricular zone form floating multicellular spheres, so-called neurospheres, in the presence of epidermal growth factor (EGF) or basic fibroblast growth factor (bFGF) under appropriate conditions (Reynolds and Weiss, 1992; Richards et al., 1992; Morshead et al., 1994). These cells self-renew and are multipotent as they give rise to neuronal, astrocytic, and oligondendrocytic cells (Reynolds and Weiss, 1992). Doetsch et al. (2002) suggested that most of the EGF-responsive neurosphere-forming cells correspond to the rapidly dividing Distal-less homeobox 2-positive type C cells. Morshead and van der Kooy (2003) proposed that precursors of these cells give rise to neurospheres.

In principle, the in vitro differentiation of neurosphereforming cells includes five steps: (1) cessation of proliferation, (2) attachment of the neurosphere, (3) detachment of cells from the neurosphere cell cluster, (4) migration of these cells away from the sphere, and (5) their actual differentiation into different cell types. These steps are comparable with adult neurogenesis of rodents in vivo; however, few of the underlying molecular changes are known. To learn more about the early and probably decisive mechanisms of this process, we have studied dynamic gene expression changes during the first $4 \mathrm{~d}$ of in vitro neurosphere differentiation with cDNA microarrays. We identified genes with relevant expression changes during this process and classified the results according to functional categories. Expression changes of selected genes were confirmed by semiquantitative RT-PCR. Because neurosphere cultures are not homogeneous (Suslov et al., 2002) and give rise to different cell types in vitro, we performed immunostainings to assign some of the most interesting results to specific cell types. We correlate our findings with the in vivo situation in the SVZ by staining tissue sections of adult mouse brains. 
Our study revealed genes known or suggested to play a role in neurogenesis, but in addition revealed many new interesting genes with potential relevance for the maintenance, migration, and differentiation of neural progenitor cells.

\section{Materials and Methods}

For the nomenclature of mouse genes and proteins, we followed the guidelines of the international committee on standardized genetic nomenclature for mice (http://www.informatics.jax.org/mgihome/nomen/).

Cell culture. Neural progenitor cells were prepared from postnatal day 7 (P7) CD1 mice (Charles River, Wilmington, MA). Cells obtained from 10 animals were used for each series [BDNF and Neurotrophin-4 (NT4), see below]. Briefly, animals were killed, and tissue including the subventricular zone was dissected out from frontal sections. The tissue was digested with Accumax (PAA Laboratories, Coelbe, Germany) for 10 min at $37^{\circ} \mathrm{C}$, fragmented with a cell strainer $(40 \mu \mathrm{m}$; BD Falcon, Heidelberg, Germany), and plated out in suspension cell flasks (Nunc, Wiesbaden, Germany) at 50,000-100,000 cells per milliliter in DMEM/F12 (1:1) with Glutamax, B27, HEPES (10 mM), insulin $(20 \mu \mathrm{g} / \mathrm{ml})$, penicillin $(100$ $\mathrm{U} / \mathrm{ml})$, streptomycin $(100 \mathrm{U} / \mathrm{ml})$, fungizone $(2.5 \mu \mathrm{g} / \mathrm{ml})$, and human recombinant EGF ( $20 \mathrm{ng} / \mathrm{ml}$ ) (all from Invitrogen, Karlsruhe, Germany). Cells were incubated at $37^{\circ} \mathrm{C}$ in $5 \% \mathrm{CO}_{2}$. After $8-11 \mathrm{~d}$ in culture, neurospheres were dissociated by incubation with Accumax, as above, followed by careful trituration, and replated at 50,000-100,000 cells per milliliter. For differentiation, tertiary spheres were used after $27 \mathrm{~d}$ in culture. Spheres were plated out in cell culture dishes coated with poly-L-lysine (Sigma, Munich, Germany) in the same medium without EGF, but with human recombinant BDNF or NT4 (20 ng/ml; Promega, Mannheim, Germany). For immunofluorescence analysis, spheres were grown on poly-L-lysine-coated coverslips.

For differentiation in Matrigel, spheres were resuspended in ice-cold Matrigel (200 $\mu \mathrm{l}$; BD Biosciences, Heidelberg, Germany) diluted with $75 \mu \mathrm{l}$ of L15-medium (Sigma) and spread on coverslips. After incubation at $37^{\circ} \mathrm{C}$ for $30 \mathrm{~min}$, Neurobasal medium supplemented with B27, HEPES (10 mM), penicillin $(100 \mathrm{U} / \mathrm{ml})$, streptomycin $(100 \mathrm{U} / \mathrm{ml})$, fungizone $(2.5 \mu \mathrm{g} / \mathrm{ml})$, glutamine ( $2 \mathrm{~mm}$ ), and human recombinant EGF $(20 \mathrm{ng} / \mathrm{ml}$ ) (all from Invitrogen) was added, and cells were incubated for $3 \mathrm{~d}$ at $37^{\circ} \mathrm{C}$ in $5 \% \mathrm{CO}_{2}$.

Pictures of cultured cells were taken with an Axiovert 100 microscope (Zeiss, Oberkochen, Germany) and a digital CCD camera DSC-S75 (Sony, Tokyo, Japan).

Generation of cDNA microarrays. Murine cDNA clones $(n=10,080$; arrayTAG clone collection) were purchased from LION Bioscience (Heidelberg, Germany), and 3510 murine cDNA clones representing brainexpressed transcripts were obtained from the resource center of the German Human Genome Project (RZPD Berlin). Clone inserts were amplified under standard conditions. Primers Lion 3' (TCG AGC GGC CGC CCG GGC AGG T) and Lion 5' (AGC GTG GTC GCG GCC GAG GT) were used for clones from LION bioscience, and primers M13for (GTA AAA CGA CGG CCA G) and M13rev (CAG GAA ACA GCT ATG AC) were used for RZPD clones. Primers were obtained from MWG Biotech (Ebersberg, Germany). In addition, 34 plant cDNA sequences and 3 murine cDNA sequences were amplified with specific primers. All PCR products were evaluated by agarose gel electrophoresis. Purified PCR products were resuspended in $8 \mu \mathrm{l}$ of $3 \times$ SSC and printed on Corning GAPS II slides by using a robotic spotting device (SDDC-2 MicroArrayer, ESI, Toronto, Canada/ChipWriter Pro, Bio-Rad, Munich, Germany) with SMP3 pins from TeleChem International (Sunnyvale, CA).

RNA isolation and microarray hybridization. Total RNA was isolated with Trizol reagent (Invitrogen). Microarray labeling and hybridization reactions were performed using the 3DNA Array 50 Expression Array Detection kit (Genisphere, Hatfield, PA) according to the manufacturer's instructions. Briefly, $20 \mu \mathrm{g}$ of total RNA of undifferentiated and differentiated cells $(24,48$, or $96 \mathrm{hr})$ was reverse transcribed using primers with a specific capture sequence. The two cDNA samples were pooled and hybridized to the microarrays in a humidified chamber at $42^{\circ} \mathrm{C}$ for 16 hr. Dye-swap repeats were performed for each time point. Thus, six arrays were used for each series (NT4 and BDNF). Slides were washed at room temperature in $2 \times \mathrm{SSC} / 0.2 \%$ SDS for $10 \mathrm{~min}, 2 \times \mathrm{SSC}$ for $10 \mathrm{~min}$, and $0.2 \times$ SSC for $10 \mathrm{~min}$. Bound CDNA was visualized by hybridization with 3DNA (dendrimers specific for respective capture sequences conjugated to either $\mathrm{Cy} 3$ or $\mathrm{Cy} 5$ ) in a humidified chamber at $42^{\circ} \mathrm{C}$ for $3 \mathrm{hr}$. Subsequently, slides were washed as before.

Image acquisition and data analysis. Fluorescence intensities of $\mathrm{Cy} 3$ and Cy5 were measured separately at 532 and $635 \mathrm{~nm}$ with a laser scanner (Affymetrix 428 Array Scanner, Affymetrix). The resulting 16-bit data files were imported into Microarray Suite image analysis software (version 2.0), which runs as an extension of IPLab Spectrum software (Scanalytics, Fairfax, VA). Raw spot intensities of Cy3 and Cy5 were locally background subtracted by the MicroArray Suite software. Empty spots and spots carrying plant gene sequences were excluded from further analysis. Each dye swap experiment was normalized by applying variance stabilization (Huber et al., 2002) using the vsn package of bioconductor (http://www.bioconductor.org). Means of normalized log-products and log-ratios of each dye swap experiment pair were used for further analysis. Normalization procedures were performed using R (http://cran.R-project.org).

Identification of differentially expressed genes and cluster analysis. First, the dataset was reduced to 454 clones that showed an estimated fold change of at least 2.0 at one differentiation time-point in both experiments (BDNF and NT4).

The threshold of estimated 2.0-fold change was determined by a statistical analysis aimed at minimizing the percentage of false positives. To do so, a variance estimation using a pooled estimate of the variance over all genes of three self-to-self comparisons with RNA from undifferentiated cells was performed. A similar approach has been described by Sabatti et al. (2002). To use a robust variance measurement, we determined the median of absolute deviation (MAD) as variance estimator. The MAD in all three independent experiments of self-to-self comparison was very similar: $0.297 \pm 0.021$. On the basis of this analysis, we can assume a rate of $2 \%$ false positives when applying a universal threshold of 2.17 -fold change. A rate of $5 \%$ false positives can be assumed when applying a threshold of 1.8-fold. We therefore chose to consider all genes above a 2.0-fold change as relevant. Thus, we can assume a false positive rate between 2 and 5\%, which we consider tolerable.

Of the clones shown in Table 1, we sequence-verified those that were present only once on the array. If a gene was represented by more clones on the array, which showed comparable expression changes, we did not sequence-verify. In this case, one representative clone is listed in Table 1.

Of the 454 clones, 441 clones showing a consistent upregulation or downregulation at the three differentiation time points were included in a cluster analysis. We clustered the 441 datasets, each representing a single time course, by applying the $k$-means algorithm and using a refined Euclidean distance measure. Ten cluster centers were randomly defined. The distance was defined as the weighted sum of $k$-means assignment and a similarity of shapes between cluster centers (gradient). The distance measure $(D)$ was defined as follows: $D(x, y)=a d 1(x, y)+$ $(1-a) d 2(x, y)$, where $a=0.5, x, y=$ two gene profiles to be compared, $d 1$ represents the Euclidean distance between $x$ and $y$, and $d 2$ represents the gradient of $x$ and $y$. These calculations and the respective visualization were performed using MATLAB (version 6.0.0.88, release 12, MathWorks).

Reverse transcription and semiquantitative PCR. Two micrograms of total RNA from each of the four time points were reverse-transcribed into cDNA by incubation with $5 \mu$ l of Deoxyribonucleoside triphosphate solution (dNTPs) (10 mM of dATP, dCTP, dTTP, dGTP each), $2.5 \mu \mathrm{l}$ of random primer $(500 \mathrm{ng} / \mu \mathrm{l})$, nuclease-free water, $10 \mu \mathrm{l}$ of Moloney murine leukemia virus (M-MLV) $5 \times$ reaction buffer, $2 \mu \mathrm{l}$ of RNasin, and $800 \mathrm{U}$ of M-MLV RT (all from Promega) for $1 \mathrm{hr}$ at $37^{\circ} \mathrm{C}$. PCR reactions were performed using equal amounts of cDNA as template, $2.5 \mu \mathrm{l}$ of dNTPs ( 2 mm each), $2.5 \mu \mathrm{l}$ of $10 \times$ reaction buffer, $1.5 \mu$ l of each primer $(10 \mathrm{pmol} / \mu \mathrm{l})$, water, and $2 \mu \mathrm{l}$ of Red Taq (Promega). Amplifications consisted of $21-26$ cycles $\left(94^{\circ} \mathrm{C}\right.$ for $45 \mathrm{sec}, 54-57^{\circ} \mathrm{C}$ for $60 \mathrm{sec}$, and $72^{\circ} \mathrm{C}$ for $90 \mathrm{sec}$ ). PCR products were visualized by agarose electrophoresis. Gene-specific primers and annealing temperatures are provided as supplementary material. 
Immunofluorescence. Cells were grown on coverslips, fixed by sequential incubation in ice-cold methanol $(5 \mathrm{~min})$ and acetone $(30 \mathrm{sec})$, and stored at $-20^{\circ} \mathrm{C}$. Cryostat sections $(10 \mu \mathrm{m})$ of brains from 3-month-old $\mathrm{CD} 1$ mice were placed on glass slides, fixed in $-20^{\circ} \mathrm{C}$ cold acetone for 10 min, and air dried. If not used immediately, slides were stored at $-80^{\circ} \mathrm{C}$ until use. Cells used for galactosyl cerebroside (GALC) staining were fixed in $4 \%$ paraformaldehyde/PBS.

Sections and coverslips were treated with Triton X-100 (0.1\% in PBS) for $5 \mathrm{~min}$ (except for GALC staining), washed with PBS three times (5 min each), and blocked with 5\% donkey serum (Dianova, Hamburg, Germany) in PBS for 30 min at room temperature. Primary antibodies were applied for $16 \mathrm{hr}$ at $4^{\circ} \mathrm{C}$ or for $45 \mathrm{~min}$ at room temperature. $\mathrm{PBS}$ without primary antibody was used as a negative control. The following primary antibodies were used: tubulin- $\beta$-III ( $1: 150$; Upstate, Charlottesville, VA), glial fibrillary acidic protein (GFAP) (polyclonal, 1:100; Santa Cruz Biotechnology, Santa Cruz, CA), GFAP (1:100, MAB3402 monoclonal; Chemicon, Temecula, CA), nestin (1:100; Transduction Laboratories, Lexington, KY), Ki-67 (1:100; Dako Cytomation, Hamburg, Germany), protein tyrosine phosphatase, nonreceptor type substrate 1 (PTPNS1) (1:200; BD Biosciences), CD47 antigen (CD47) (1:200; BD Biosciences), FABP7 (1:100; kindly provided by T. Mueller, C. Birchmeier, MDC, Berlin, Germany), pleiotrophin (1:100; R \& D Systems, Minneapolis, MN), HUC/D (1:100; Molecular Probes, Eugene, OR), CD24 antigen (CD24) (1:100; Santa Cruz Biotechnology), polysialylated neural cell adhesion molecule (PSA-NCAM) (1:100; AbCys, Paris, France), galactosylceramidase (GALC) (1:100; Roche). After three washes in PBS (15 min each), secondary antibodies coupled to Cy3 or fluorescein isothiocyanate (Dianova) were applied for $30 \mathrm{~min}$ at room temperature. Specimens were then washed three times in PBS (15 min each), rinsed briefly in water, dehydrated in ethanol, and air dried. A mounting medium containing $4^{\prime}, 6^{\prime}$-diamidino-2-phenylindole (DAPI) nuclear stain was used. Immunofluorescence was documented with a Zeiss Axioskop epifluorescence microscope (Zeiss) or with a Leica DM IRE2 (Leica, Wetzlar, Germany).

\section{Results}

\section{In vitro differentiation of neurosphere cells}

Soon after the transfer of neurospheres into poly-L-lysine-coated dishes with a medium that contained no EGF, but did contain BDNF or NT4, they attached to the plate. By $24 \mathrm{hr}$ a few cells had migrated out of the spheres. This number increased with time, and migrating cells underwent morphological changes (Fig. 1). Cells in close proximity to the sphere appeared as large flat glialike cells, and they were immunopositive for the astrocyte marker GFAP (Fig. 2). In contrast, some cells that migrated farther away from the sphere acquired a neuronal morphology with small cell bodies and long, slim processes. These stained positive for the neuron-specific marker tubulin- $\beta$-III (Fig. 2). Most cells within the spheres were positive for GFAP; however, after $96 \mathrm{hr}$ the compact sphere structure had frequently loosened up, and some of these cells had changed their morphology as well. Few cells inside the spheres produced tubulin- $\beta$-III after induction of differentiation, whereas most differentiating cells were GFAP positive. Very few cells were positive for the oligodendrocyte marker GALC (data not shown).

To test for cell proliferation, we immunostained with an antibody against Ki-67, a marker for dividing cells (Gerdes et al., 1983). Before induction of differentiation, some cells within neurospheres were positive for Ki-67; however, $24 \mathrm{hr}$ after induction of differentiation, no more dividing cells were found (Fig. 2). This is in line with our microarray results (see Gene expression changes related to cell proliferation). We also immunostained the cells for nestin, a marker present in neuroepithelial precursor cells. Before and after induction of differentiation, neurosphere clusters were nestin-positive; however, cells that had migrated away from the spheres no longer expressed nestin (Fig. 2).
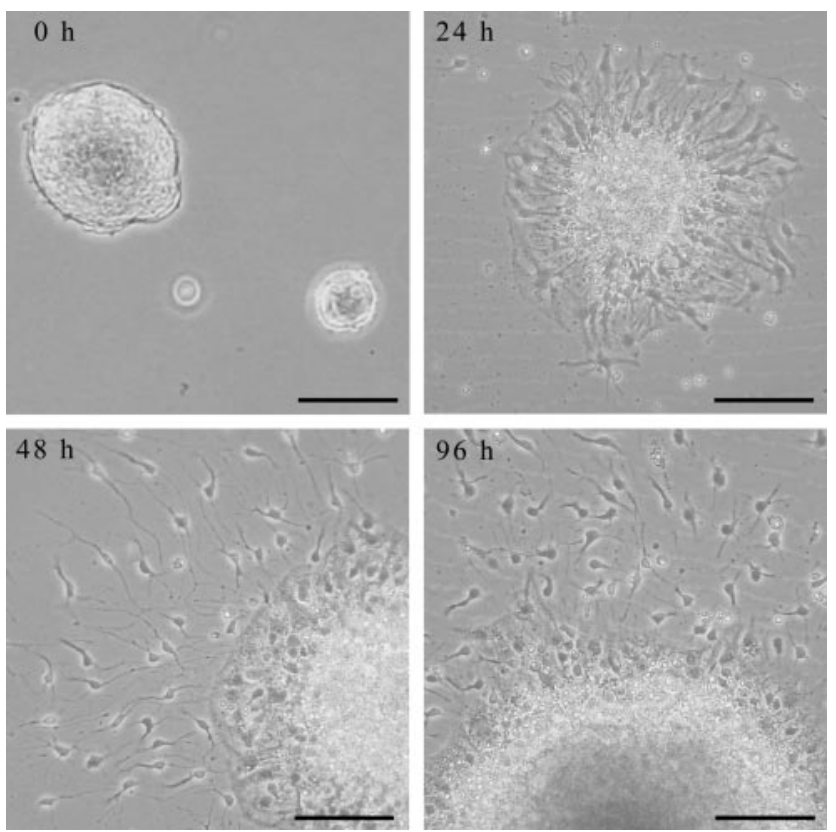

Figure 1. Photographs depicting morphological changes in the course of neural progenitor cell differentiation in vitro. Undifferentiated neurospheres before and cells at 24, 48, and $96 \mathrm{hr}$ after induction of differentiation are shown. Scale bar, $50 \mu \mathrm{m}$.

\section{Gene expression changes: general findings}

We performed cDNA microarray co-hybridizations with cDNA samples derived from cells of two experimental series (BDNF and NT4). Neurosphere cells were kept in culture for two passages and then pooled and redistributed before differentiation with either BDNF or NT4. Cells were harvested at time points 0 (undifferentiated cells), 24, 48, and $96 \mathrm{hr}$ after induction of differentiation. For each series, three co-hybridizations, 0 versus $24 \mathrm{hr}, 0$ versus $48 \mathrm{hr}$, and 0 versus $96 \mathrm{hr}$ were performed and repeated with fluorescent dyes swapped to compensate for dye-specific effects. The six resulting single datasets per series were subjected to further analysis that involved a normalization step (see Materials and Methods), resulting in three datasets per series, one for each co-hybridization $(24,48$, and $96 \mathrm{hr})$. To identify relevant differentially expressed genes, all clones with more than twofold estimated differences in expression in at least one of the three datasets were considered for further evaluation. This threshold is based on a statistical analysis as described in Materials and Methods.

Seven hundred twenty-two clones of the BDNF experiment and 624 clones of the NT4 experiment fulfilled this criterion. Eighty-three percent of the clones from the BDNF series showed at least a 1.6-fold estimated change in the NT4 experiment, and $84 \%$ of the clones from the NT4 series showed at least a 1.6-fold estimated change in the BDNF experiment. Four hundred fiftyfour clones exhibited relevant (more than twofold) expression changes under both conditions. Of these, 97.1\% were consistently upregulated ( 271 clones) or downregulated ( 170 clones) at the three time points (negative or positive log ratio of signal intensity) compared with undifferentiated cells in both series. Thirteen clones $(2.9 \%)$ showed an upregulation at one time point and subsequent downregulation or vice versa (e.g., phosphoglucose isomerase 1) (Table 1, metabolism, NT4 series). The overlap of results from these two independent experiments suggests that the neurotrophins BDNF and NT4, both of which bind to the TrkB receptor, lead to mostly overlapping gene expression changes. All further analyses were limited to the 454 clones of the 
$0 \mathrm{~h}$
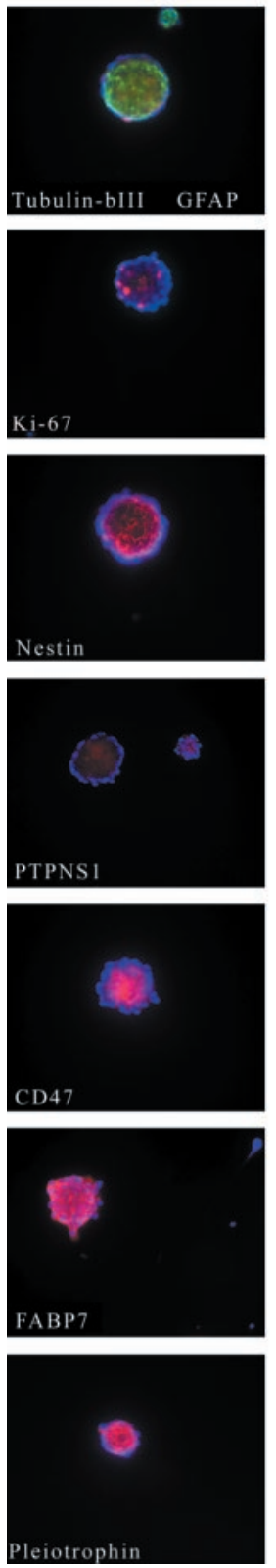

$24 \mathrm{~h}$
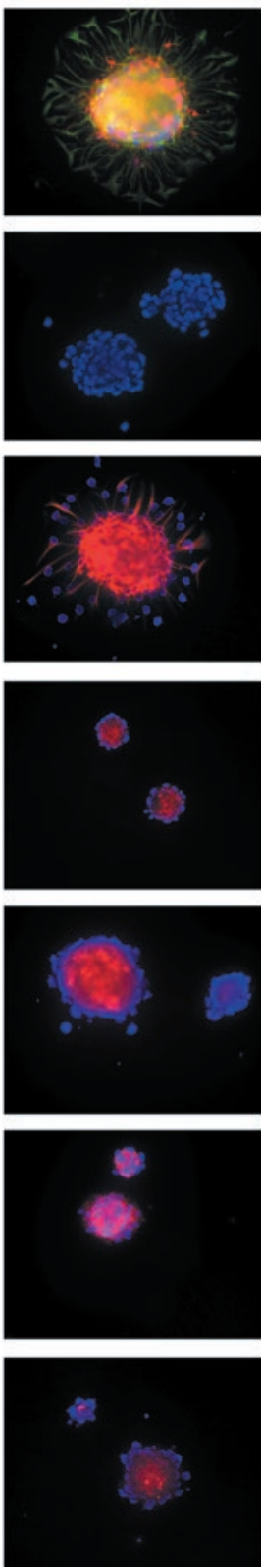

$48 \mathrm{~h}$
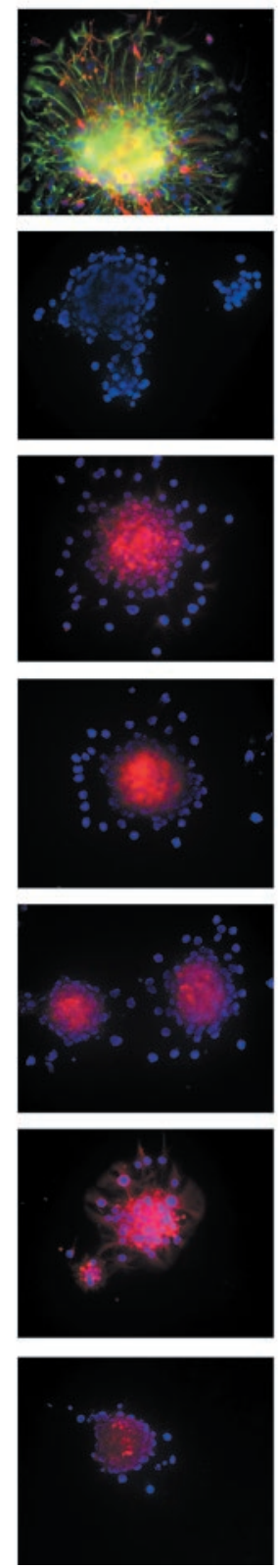

Figure 2. Immunofluorescence microscopy of undifferentiated neurospheres and of cells at 24,48 , and $96 \mathrm{hr}$ after induction of differentiation. Cells were immunolabeled with antibodies against tubulin- $\beta$-III, Ki-67, Nestin, PTPNS1 (SHPS-1), CD47, FABP7, Pleiotrophin (all red), and GFAP (green). Nuclei are stained blue. Note the different staining of undifferentiated neurosphere clusters and differentiating cells. Scale bar, $100 \mu \mathrm{m}$.

intersection list, thus concentrating only on the commonalities associated with the TrkB receptor activation in the two experimental series. They were grouped into 10 different categories (Table 1) (see below).

The complete dataset (MIAMI standards) including remaining clones with relevant expression changes, which are not listed in these groups, can be found on our homepage (http://www.molgen. mpg.de/ dna_microarrays/neural_differentiation/neural.html).

To extract the dynamic behavior of the relevant gene expression changes in the course of neural progenitor differentiation, cluster analysis was performed using the 441 consistently upregulated or downregulated clones from the intersection list (see Materials and Methods). We grouped the 441 clones into 10 clusters that show a similar onset and course of transcriptional changes
$96 \mathrm{~h}$
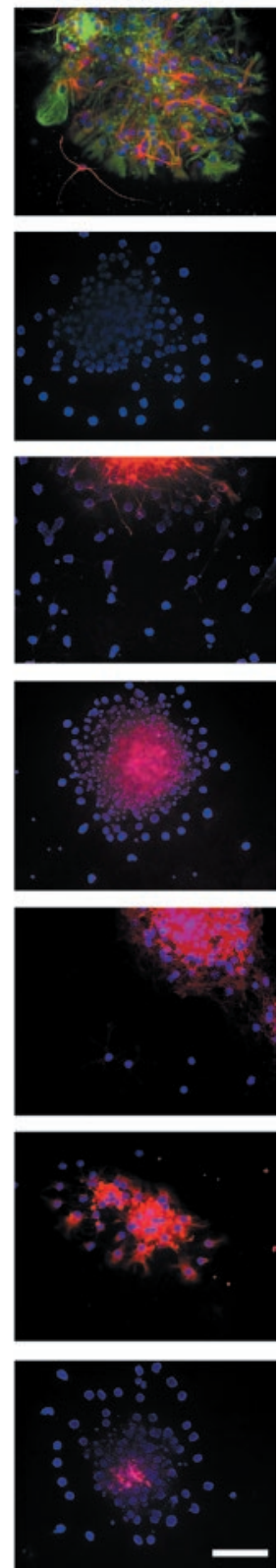

(Fig. 3A): clusters $1-5$ containing upregulated and clusters $6-10$ containing downregulated genes, both in the BDNF and NT4 series. With the exception of clusters 7 and 8 , there is a large fraction of clones in each cluster that occur in both series (Fig. $3 B$, Table 1). Most genes fall into clusters that display only slight expression changes (clusters 2, 4, 5, 6, 7, 10). Clusters 1 and 3 contain strongly upregulated genes, and clusters 8 and 9 contain strongly downregulated genes. Concerning the dynamics, genes that change late in expression are found especially in cluster 2. Genes that change very early (between time point 0 and $24 \mathrm{hr}$ ) are found in two of the four clusters with strongest changes (clusters 1 and 9); in addition, they are found in cluster 6. Downregulated genes of the functional category "chromatin-associated components and nuclear factors," in particular, fall into clusters 6 and 10, which contain slightly decreasing transcript levels. Cluster 9 includes numerous cell cyclerelated genes. Cluster 2 (late upregulated transcripts) contains many genes that localize to the cell membrane or are found in cellular extensions. Apart from these findings, single clusters do not preferentially contain genes of a certain category. The 10 genes with highest expression changes at one time point were $I g f b p 2(16.28 / 25.79)$ (highest fold-change in BDNF experiment/highest fold-change in NT4 experiment), 6330403K07Rik (10.91/14.01), PDZ-binding kinase (10.49/7.24), Cdc2/ p34 (10.07/9.49), Igfbp4 (9.87/8.85), Fxyd1/Plm (7.85/7.77), Cyclin D1 (6.36/7.69), Complement component 3 (7.61/6.89), $C d c 20$ (7.10/6.96), and an EST adjacent to cadherin $13(6.69 / 5.87)$.

\section{Cell type-specific gene} expression changes

We investigated very early differentiation stages of neurosphere cells to determine the basic molecular changes that underlie the conversion of the progenitor cell toward a cell that enters a differentiation process. In vitro, neurosphere cells differentiate into three major types of cells: neurons, astrocytes, and oligodendrocytes (Reynolds and Weiss, 1992). In addition to a functional categorization, we also screened our data for cell type-specific genes and found expression changes that already point to a cellular specification. Several genes typical for neurons and oligodendrocytes were found, all of them upregulated, and many only at a late time point of differentiation $(96 \mathrm{hr})$. With the exception of the myelin basic protein gene in the NT4 series, none of them falls into cluster 1 . Two genes characteristic for astrocytes were found: $S 100 B$ is upregulated, deiodinase iodothyronine type II is downregulated.

Concerning oligodendrocyte-specific genes, we found an increased expression of many myelin components. Of note is the temporal sequence of myelin component upregulation: tran- 
Table 1. Gene expression changes in neural progenitor cells during differentiation

\begin{tabular}{|c|c|c|c|c|c|c|c|c|c|c|c|}
\hline \multirow[b]{2}{*}{ Gene } & \multirow[b]{2}{*}{ Trend } & \multirow[b]{2}{*}{ Cluster } & \multicolumn{3}{|c|}{ Fold change (BDNF) } & \multirow[b]{2}{*}{ Cluster } & \multicolumn{3}{|c|}{ Fold change (NT4) } & \multirow[b]{2}{*}{ Accession number } & \multirow[b]{2}{*}{ Mentioned previously } \\
\hline & & & $24 \mathrm{hr}$ & $48 \mathrm{hr}$ & $96 \mathrm{hr}$ & & $24 \mathrm{hr}$ & $48 \mathrm{hr}$ & $96 \mathrm{hr}$ & & \\
\hline Cell-cell adhesion & & & & & & & & & & & \\
\hline Cadherin 13 & - & 7 & 1.35 & 2.97 & 3.10 & 7 & 1.12 & 3.03 & 3.42 & NM_019707 & $1,5,6$ \\
\hline EST adjacent to cadherin 13 & - & 9 & 1.52 & 4.90 & 6.69 & 8 & 1.45 & 4.48 & 5.87 & AW121058 & $1,5,6$ \\
\hline $\mathrm{Cd} 24$ & + & 2 & 1.57 & 1.73 & 2.23 & 2 & 1.49 & 1.82 & 2.39 & AW553321 & 4,6 \\
\hline $\begin{array}{l}\text { Close homolog of the neural adhesion } \\
\text { molecule L1 }\end{array}$ & - & 6 & 1.88 & 2.36 & 2.36 & 7 & 1.65 & 2.77 & 2.80 & Al528777 & 5 \\
\hline Epithelial membrane protein 3 & + & 2 & 1.31 & 1.14 & 2.39 & 2 & 1.12 & 1.26 & 2.05 & AW912730 & \\
\hline Neurexin II & + & 4 & 1.77 & 1.86 & 2.03 & 4 & 1.72 & 2.03 & 1.99 & BE286506 & \\
\hline Plakophilin-4 (p0071 protein) & + & 5 & 1.84 & 3.00 & 3.35 & 5 & 1.58 & 3.10 & 3.49 & Al837226 & \\
\hline $\begin{array}{l}\text { Extracellular matrix components and cell- } \\
\text { matrix interaction }\end{array}$ & & & & & & & & & & & \\
\hline Adamts10 & + & 2 & 1.52 & 1.70 & 2.44 & 2 & 1.60 & 1.72 & 2.01 & BG064835 & \\
\hline AE binding protein 1 & + & 2 & 1.25 & 1.16 & 2.97 & 4 & 1.58 & 2.27 & 2.03 & BF118240 & \\
\hline Collagen IX $\alpha 3$ & + & 4 & 2.16 & 2.12 & 1.72 & 4 & 2.08 & 1.82 & 1.60 & AV006866 & 5 \\
\hline Collagen XVIII & - & 10 & 1.36 & 1.68 & 2.51 & 10 & 1.38 & 1.68 & 2.01 & U03714 & 6 \\
\hline Complement component $1 \mathrm{q} \beta$ & + & 4 & 2.29 & 2.48 & 2.75 & 5 & 2.01 & 2.56 & 3.19 & AW208835 & \\
\hline Complement component 3 & + & 1 & 2.27 & 7.24 & 7.61 & 1 & 1.55 & 4.31 & 6.89 & Al790152 & \\
\hline Complement component 4 & + & 1 & 4.10 & 5.47 & 6.17 & 1 & 3.60 & 6.23 & 6.17 & BE369103 & \\
\hline Complement component factor i & + & 3 & 1.42 & 2.18 & 3.32 & 3 & 1.07 & 2.44 & 3.06 & BG072327 & \\
\hline Extracellular matrix protein 2 (Sparc-like 1) & + & 5 & 2.25 & 3.19 & 3.49 & 5 & 1.63 & 3.06 & 3.56 & W36427 & \\
\hline Inter- $\alpha$ trypsin inhibitor heavy chain 3 & + & 3 & 2.12 & 2.46 & 4.31 & 3 & 1.82 & 3.29 & 4.06 & NM_008407 & \\
\hline Laminin receptor 1 & - & 10 & 1.31 & 1.67 & 2.03 & 10 & 1.57 & 1.63 & 2.39 & W13846 & 6 \\
\hline Serpina3 & + & 2 & 1.39 & 1.39 & 2.29 & 4 & 2.03 & 1.55 & 1.68 & BE200266 & \\
\hline SH3 domain protein 4 (Vinexin/ SCAM-1) & + & 3 & 1.03 & 1.70 & 3.39 & 2 & 1.17 & 1.75 & 2.18 & AW540876 & \\
\hline Tenascin C & - & 7 & 1.62 & 2.53 & 2.36 & 6 & 2.12 & 2.25 & 1.72 & Al157473 & $2,4,5,6$ \\
\hline Tissue inhibitor of metalloproteinase 2 & + & 4 & 2.20 & 2.41 & 3.16 & 5 & 1.79 & 2.72 & 2.92 & W41950 & 5 \\
\hline Tissue inhibitor of metalloproteinase 3 & + & 4 & 2.44 & 1.88 & 1.95 & 4 & 1.80 & 2.01 & 2.14 & AA712082 & 2 \\
\hline Cytoskeleton & & & & & & & & & & & \\
\hline Actinin, $\alpha 1$ (Striamin) & + & 5 & 2.18 & 2.89 & 2.92 & 5 & 1.67 & 2.59 & 2.48 & BE688759 & \\
\hline Active $B C R$-related gene & + & 5 & 1.72 & 3.10 & 3.16 & 5 & 1.75 & 3.03 & 2.72 & BF449832 & \\
\hline Adducin 3 & + & 4 & 1.75 & 1.97 & 2.18 & 4 & 1.82 & 2.23 & 2.18 & AA500258 & \\
\hline Arhgap18 & - & 6 & 2.20 & 2.86 & 2.53 & 10 & 1.90 & 2.20 & 2.77 & BG071822 & \\
\hline Arhgap5 & + & 4 & 1.49 & 2.03 & 1.48 & 2 & 1.23 & 1.38 & 2.03 & NM_009706 & 5 \\
\hline Cdc42 effector protein 4 & + & 3 & 1.42 & 2.48 & 3.16 & 3 & 1.48 & 2.16 & 2.94 & Al844806 & 6 \\
\hline $\mathrm{N}$-chimerin & - & 6 & 1.97 & 2.80 & 2.86 & 10 & 2.18 & 2.36 & 3.29 & BG088668 & \\
\hline Coronin actin binding protein $1 C$ & - & 10 & 1.40 & 1.99 & 2.08 & 10 & 1.46 & 1.93 & 2.18 & AW455561 & \\
\hline Cysteine-rich protein 1 & + & 4 & 1.75 & 2.39 & 2.29 & 4 & 2.08 & 2.12 & 2.18 & W18400 & 5 \\
\hline Dynein, axonemal, heavy polypeptide 7 & + & 4 & 3.00 & 1.79 & 2.80 & 4 & 2.53 & 3.42 & 1.86 & BG292586 & \\
\hline Dynein, cytoplasmic, light chain 2B & + & 2 & 1.54 & 1.68 & 2.05 & 2 & 1.52 & 1.31 & 2.16 & BG083926 & \\
\hline Ezrin (villin 2) & + & 4 & 2.25 & 1.93 & 2.44 & 2 & 1.82 & 2.05 & 2.53 & AA139292 & 6 \\
\hline Gelsolin & + & 1 & 3.00 & 4.71 & 6.05 & 1 & 2.69 & 4.35 & 6.11 & Al848142 & \\
\hline Kinesin heavy chain member 5B & + & 4 & 1.70 & 2.10 & 2.16 & 2 & 1.40 & 1.46 & 2.29 & Al892690 & 4 \\
\hline Leucine-rich repeat (in FLII) interacting & & & & & & & & & & & \\
\hline protein 1 & - & 8 & 1.86 & 1.23 & 2.92 & 10 & 1.40 & 2.10 & 3.06 & Al461880 & $2,4,6$ \\
\hline Neuronal protein 4.1 & + & 2 & 1.60 & 1.70 & 2.16 & 2 & 1.32 & 1.80 & 2.41 & AW049949 & \\
\hline Plexin B3 & + & 4 & 1.31 & 2.05 & 1.99 & 4 & 1.51 & 2.41 & 2.16 & BE136019 & \\
\hline Rac GTPase-activating protein 1 & - & 10 & 1.70 & 2.05 & 1.82 & 10 & 1.80 & 1.92 & 2.10 & AB030252 & $1,2,5,6$ \\
\hline S100 calcium binding protein A1 & + & 4 & 1.49 & 1.95 & 2.36 & 2 & 1.27 & 1.73 & 2.36 & AK012578 & 2 \\
\hline S100 calcium-binding protein A4 & + & 5 & 1.88 & 2.41 & 2.72 & 5 & 1.77 & 2.66 & 3.32 & X05835 & \\
\hline S100 calcium-binding protein A6 & + & 3 & 1.84 & 2.32 & 3.19 & 5 & 1.90 & 2.36 & 3.10 & AK008241 & 2 \\
\hline S100 protein $\beta$ polypeptide neural & + & 5 & 1.70 & 2.80 & 3.74 & 3 & 1.22 & 2.72 & 3.90 & Al835699 & \\
\hline Sperm-associated antigen 6 & + & 2 & 1.23 & 1.49 & 2.64 & 2 & 1.19 & 1.75 & 2.03 & NM_015773 & \\
\hline Thymosin, $\beta 10$ & - & 6 & 2.12 & 2.27 & 2.61 & 6 & 2.29 & 2.23 & 2.61 & BE135516 & 5,6 \\
\hline Transgelin 3 & + & 3 & 1.32 & 2.12 & 2.59 & 2 & 1.30 & 2.01 & 2.59 & Al426007 & \\
\hline Tropomodulin 2 & + & 4 & 1.72 & 2.20 & 2.56 & 5 & 1.57 & 2.34 & 2.41 & BB462768 & 5 \\
\hline Tubulin, $\alpha 3 / 7$ & + & 2 & 1.11 & 1.49 & 2.36 & 2 & 1.35 & 1.88 & 2.59 & NM_009446 & 4 \\
\hline Tubulin, $\beta 3$ & + & 4 & 1.86 & 1.67 & 2.10 & 4 & 1.65 & 2.29 & 1.97 & AK014302 & 5,6 \\
\hline Tubulin, $\beta 4$ & + & 5 & 1.34 & 2.86 & 2.89 & 5 & 1.54 & 3.06 & 2.86 & Al849897 & 5 \\
\hline Cell proliferation & & & & & & & & & & & \\
\hline $\operatorname{cdc} 20$ & - & 9 & 3.63 & 6.55 & 7.10 & 9 & 6.69 & 5.81 & 6.96 & C87100 & \\
\hline $\operatorname{cdc} 2 \mathrm{a}$ & - & 9 & 5.53 & 4.66 & 10.07 & 9 & 5.93 & 9.49 & 8.41 & AW990601 & $1,2,4,6$ \\
\hline Chromatin assembly factor 1 subunit $C$ & & & & & & & & & & & \\
\hline (Rbbp4) & - & 10 & 1.49 & 1.92 & 2.23 & 10 & 1.42 & 1.75 & 2.39 & AA139889 & \\
\hline Cyclin B1 & - & 6 & 3.71 & 3.35 & 3.94 & 6 & 3.32 & 3.97 & 3.03 & Al131574 & 2,4 \\
\hline Cyclin D1 & - & 9 & 5.37 & 7.69 & 6.36 & 9 & 5.26 & 6.23 & 7.69 & BE995549 & $1,2,3,4,5,6$ \\
\hline Cyclin D2 & - & 9 & 2.25 & 4.62 & 4.53 & 7 & 1.93 & 4.62 & 2.94 & NM_009829 & $1,2,3,5,7$ \\
\hline DNA polymerase $\delta 1$ & - & 8 & 2.05 & 1.40 & 2.53 & 6 & 1.79 & 2.53 & 2.36 & Al851668 & 4,6 \\
\hline DNA polymerase $\delta$ subunit 4 & - & 7 & 1.38 & 2.20 & 2.01 & 10 & 1.39 & 1.73 & 2.05 & AK010477 & \\
\hline DNA replication licensing factor MCM3 & - & 6 & 2.92 & 3.60 & 4.53 & 8 & 3.46 & 4.01 & 3.67 & BE200058 & 6 \\
\hline DNA replication licensing factor MCM6 & - & 10 & 1.45 & 1.73 & 2.01 & 10 & 1.32 & 1.73 & 2.66 & BE854336 & 2 \\
\hline
\end{tabular}


Table 1. (Table continued)

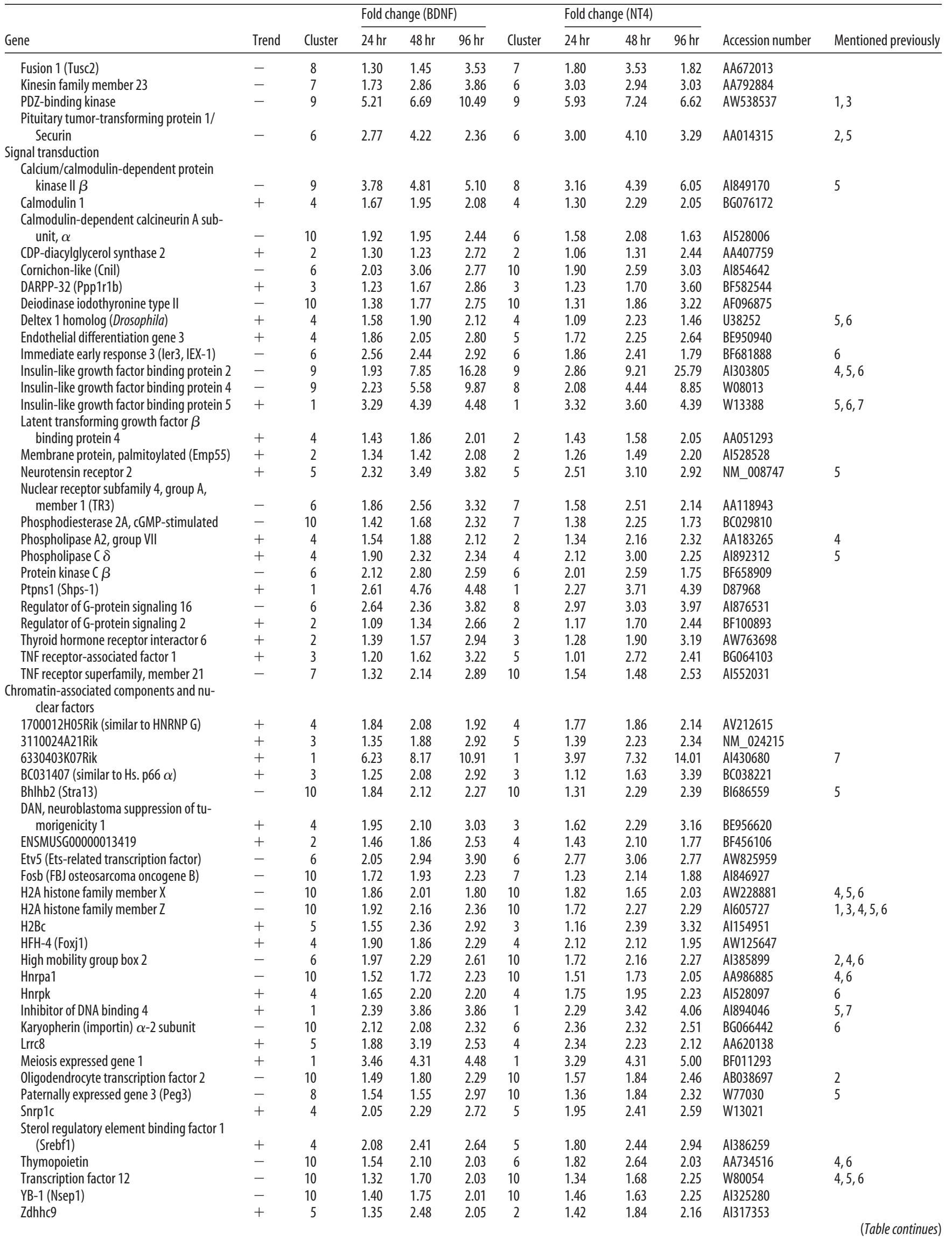


Table 1. (Table continued)

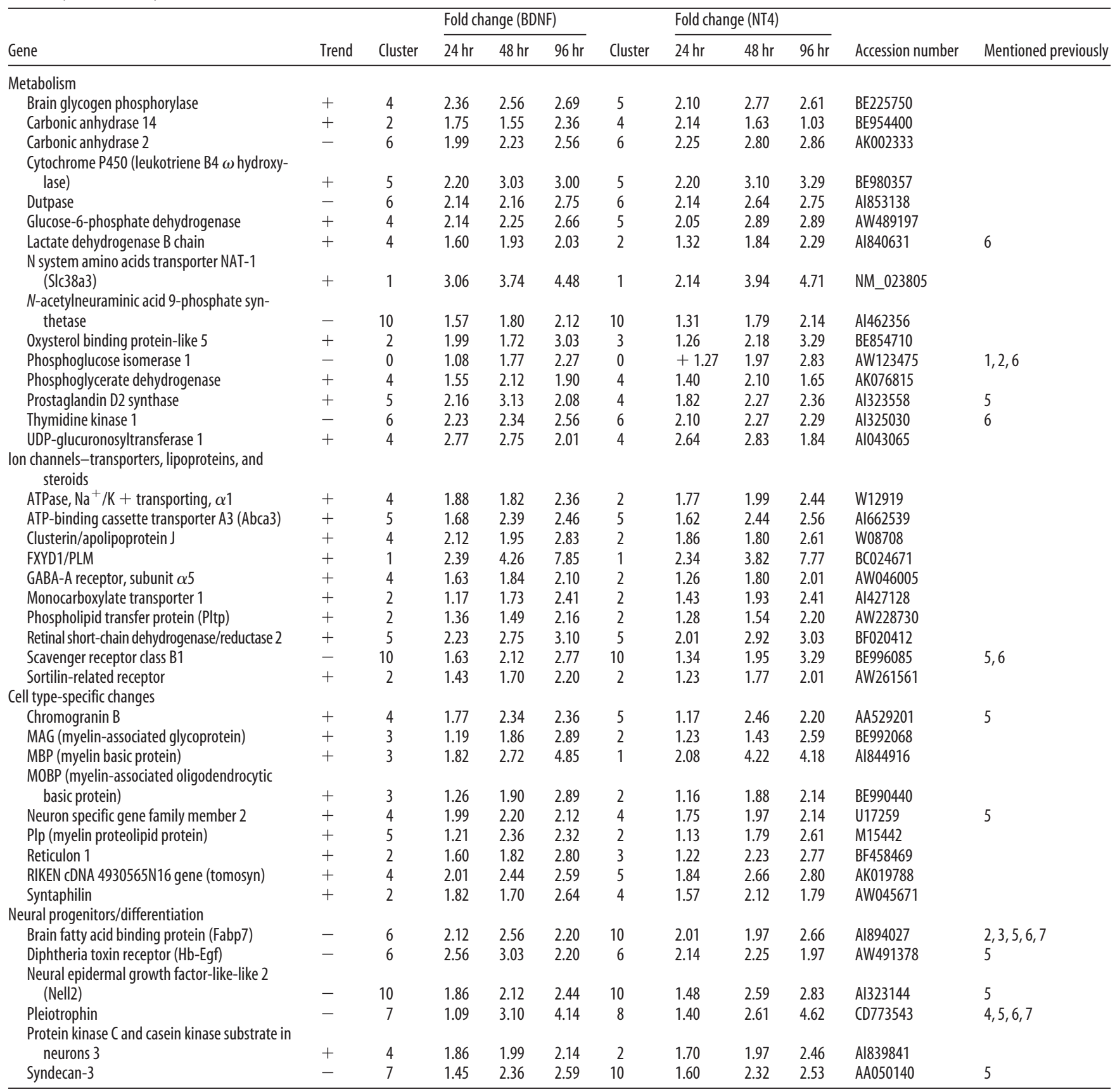

One hundred sixty-one differentially regulated genes are grouped into 10 categories of interest. The trend column indicates an upregulation ( + ) or downregulation ( - ). Fold changes at 24,48 , and $96 \mathrm{hr}$ compared with the undifferentiated state $(0 \mathrm{hr})$ in each experimental series (BDNF and NT4) are given. The numbers from the cluster analysis are indicated for each gene and experimental series. Accession numbers of representative clones are listed.

Numbers in the last column indicate studies that report a comparable expression pattern in neural stem cells. 1-3, Genes expressed higher in adult undifferentiated as compared with differentiated neurosphere cells (1: Geschwind et al., 2001;2: Karsten et al., 2003;3: Easterday et al., 2003).4-7,Genes enriched in neural progenitor-stem cells in comparison with other stem cell types (4: Ramalho-Santos et al., 2002; 5: Ivanova et al., 2002; 6: Fortunel et al., 2003; 7: D’Amour and Gage, 2002).

script levels of myelin basic protein increase first (already at $24 \mathrm{hr}$ ), whereas myelin-associated glycoprotein and myelin-associated oligodendrocyte basic protein transcripts increase more than twofold only by $96 \mathrm{hr}$.

Of neuron-specific genes, increased expression was found for Nsg2 (neuron-specific gene family member 2), Chromogranin $B$, the RIKEN cDNA 4930565N16 gene homologous to rat Tomosyn, Syntaphilin, and Reticulon 1. Additional genes confined to neurons in the nervous system were Neurexin II $\beta$, RhoN, Neuronal tropomodulin, 4.1N, tubulin- $\beta-I I I$, and Darpp-32 (see below).

\section{Gene expression changes related to cell adhesion}

Although the molecular basis for the formation of neurospheres in vitro is not known, it could be mediated by direct cell-cell adhesion or indirectly via extracellular matrix (ECM) proteins that act as adhesive substance between them. Searching our dataset for genes involved in cell adhesion and defined cell junction structures, we found Cadherin13 (H-cadherin, T-cadherin), an EST adjacent to cadherin 13, and the gene encoding Chl1 (close homolog of the neural adhesion molecule L1) to be downregulated in the course of differentiation, indicating their expression in undifferentiated neurospheres. 
A

BDNF
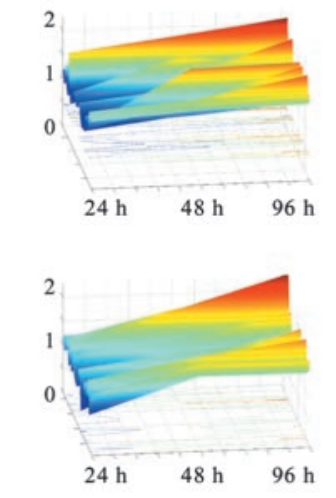

Cluster 6

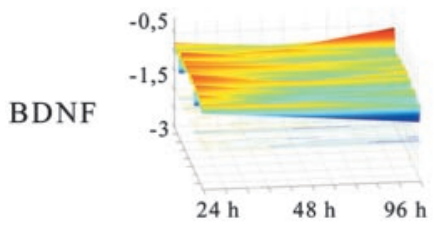

NT4

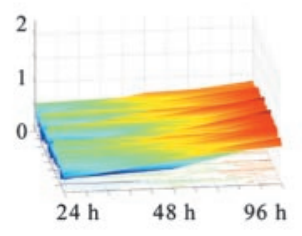

Cluster 7
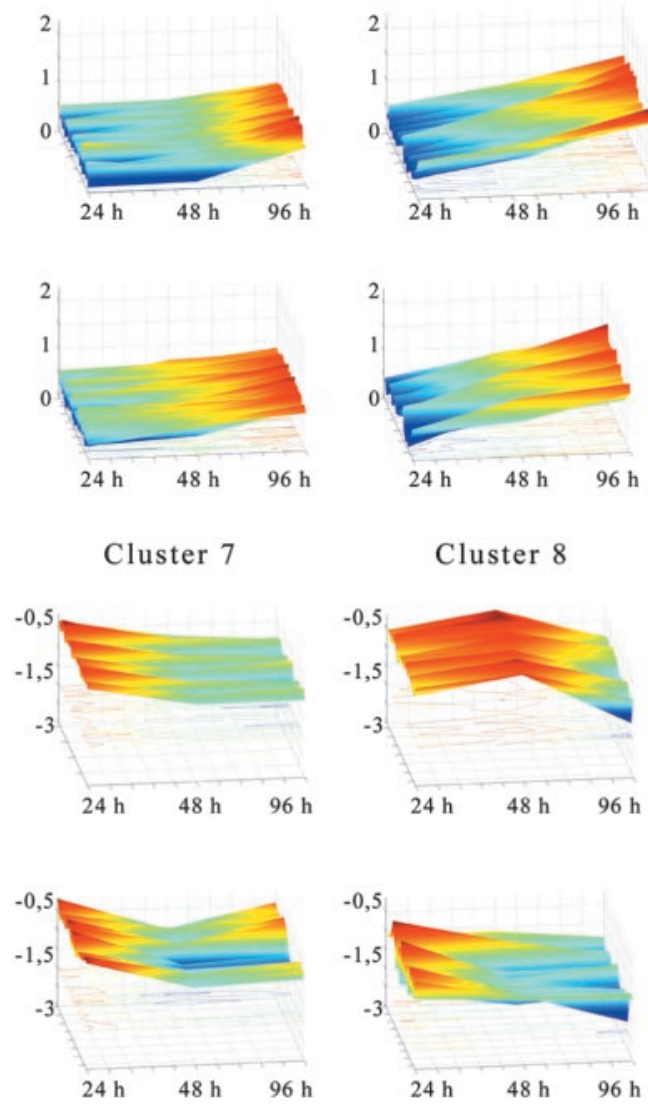

NT4

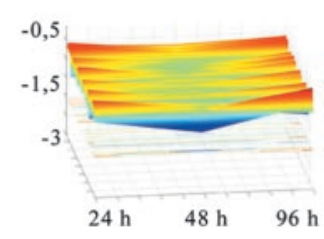

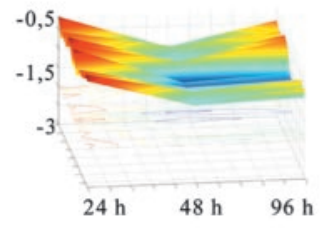

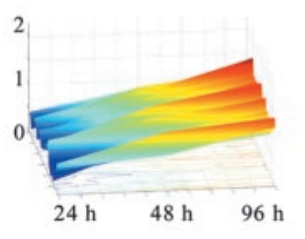

Cluster 8

Cluster 4
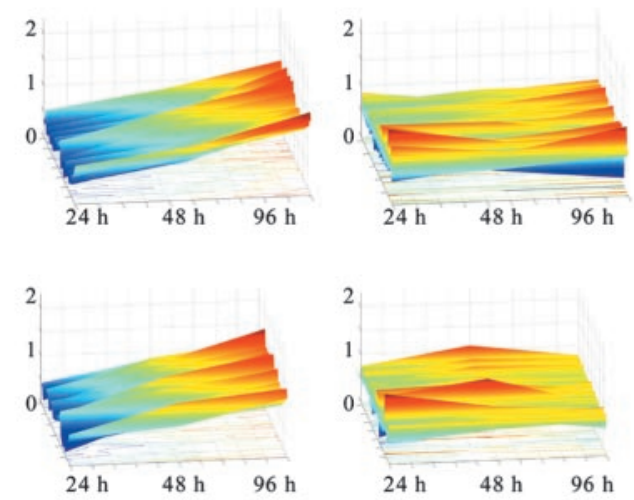

Cluster 9
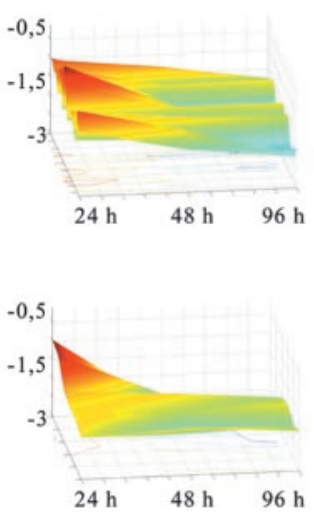

Cluster 5
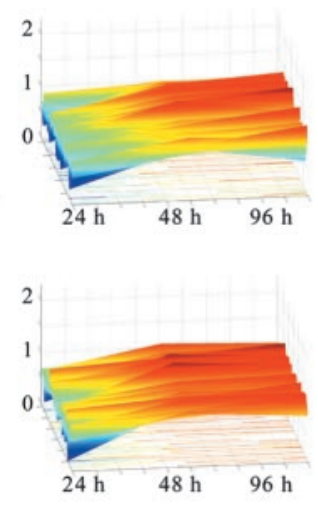

Cluster 10

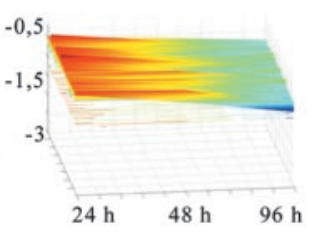

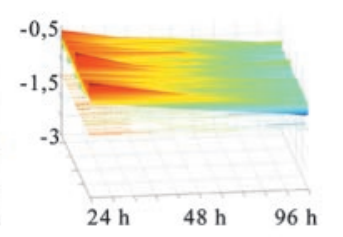

B

\begin{tabular}{llllllllllll} 
Cluster & 1 & 2 & 3 & 4 & 5 & 6 & 7 & 8 & 9 & 10 & Sum \\
\hline BDNF & 24 & 51 & 36 & 106 & 54 & 39 & 21 & 15 & 18 & 77 & 441 \\
NT4 & 22 & 82 & 30 & 74 & 63 & 39 & 16 & 18 & 6 & 91 & 441 \\
\hline Intersection & 21 & 35 & 12 & 55 & 33 & 22 & 3 & 1 & 6 & 61 & 249
\end{tabular}

Figure 3. A, Clusters of clones with similar expression changes over time. The dynamic behavior of the 441 clones that are consistently upregulated or downregulated in both the BDNF and the NT4 series is shown separately. For each series, 10 clusters were found. Clusters $1-5$ contain upregulated clones; clusters $6-10$ contain downregulated clones. The $x$-axis depicts the three time points of differentiation. The $y$-axis shows relative fold changes; that is, expression changes referred to the undifferentiated state ( $0 \mathrm{hr})$. These relative numbers are estimated logarithmic fold changes and therefore not identical to the estimated fold changes listed in Table 1. The logarithmic values allow a better graphic presentation. Note that $y$-axis values at $24 \mathrm{hr}$, which are different from the value 0 , indicate that the expression of a clone changed already between 0 and $24 \mathrm{hr}$. B, Numbers of clones contained in each cluster of the NT4 and BDNF series.

The most striking decrease, approximately sixfold at $96 \mathrm{hr}$, was seen in the case of the EST adjacent to cadherin 13. In addition, a cadherin 13 clone showed a strong transcript decrease. Cadherin 13 is a glycosylphosphatidyl inositol (GPI)-linked membrane protein that can mediate homophilic cell-cell adhesion (for review, see Takeuchi and Ohtsuki, 2001). Moreover, anti-adhesive properties and a function in cell cycle regulation have been reported (Takeuchi et al., 2000; Huang et al., 2003; Ivanov et al., 2004). Chl1 belongs to the L1 family of neural recognition molecules and promotes neurite outgrowth and neuronal survival and enhances integrin-mediated cell migration (Hillenbrand et al., 1999; Buhusi et al., 2003).

Some genes of the cell adhesion category were upregulated, suggesting a role in cellular contacts between differentiating cells: Cd24, Emp3, Neurexin II, and Plakophilin-4. The first two fall into cluster 2, which contains very late gene expression changes. None of them belongs to cluster 1. CD24 is a membrane-anchored glycoprotein expressed in the SVZ by neuroblasts (type A cells), in the SVZ ependymal cells, and in the brain parenchyma by differentiated neurons (Calaora et al., 1996; Doetsch et al., 2002). It binds to L1 on neighboring cells and has been shown to influence neurite outgrowth. The Neurexin II cDNA clone on our array shows highest similarity to a Neurexin II $\beta$ variant (for review, see Missler and Sudhof, 1998). $\beta$ Neurexins have been implicated in heterophilic cell-cell adhesion and assembly of presynaptic terminals (Dean et al., 2003). The gene encoding Plakophilin-4 (p0071 protein/Nprap), an intracellular plaque protein at adherens junctions and desmosomes in epithelial cells, shows gradually increasing transcript levels (cluster 5). The Emp3 (Hnmp-1) product belongs to the PMP22 family of tetra- 
spanning membrane proteins and is thought to be involved in cell-cell interactions and cell proliferation. The Sh3 domain protein 4 (vinexin) binds vinculin and localizes to sites of cell-matrix interactions (focal adhesions) and at cell-cell adhesions. It will be of interest to investigate the upregulated genes on the protein level to assign them to specific cell types.

\section{Gene expression changes related to extracellular matrix components}

ECM molecules serve as a scaffold for the aggregation of cells within tissues. In addition, they constitute a cellular microenvironment that influences cell behavior, including cell migration and differentiation. These processes are controlled in part by biologically active molecules such as growth factors, which are stored in the ECM.

Our study revealed three transcripts encoding ECM proteins that are downregulated in differentiated cells compared with undifferentiated, floating cells: Tenascin C, Collagen XVIII, and Laminin receptor 1 .

Tenascin C is present in the SVZ, RMS, and olfactory bulb. Specifically, it corresponds to GFAP-positive processes that form the tunnel through which SVZ neuroblasts migrate (Jankovski and Sotelo, 1996). In the embryonic brain, it is expressed by radial glial cells (Malatesta et al., 2003). Tenascin mediates adhesion of cells, either increasing or decreasing it (Jones and Jones, 2000). Collagen XVIII is a basement membrane component. One splice variant is expressed in brain (Muragaki et al., 1995; Saarela et al., 1998; Sertie et al., 2000). The downregulation of the gene encoding Laminin receptor 1 is in line with its expression in undifferentiated, mitotically active progenitor and tumor cells in contrast to differentiated forms of these cells (for review, see Menard et al., 1997).

ECM genes that were upregulated in our study encode the Adipocyte enhancer binding protein 1 (Aortic carboxypeptidaselike protein), Extracellular matrix protein 2 (Sparcl1, Mast9, Hevin), Collagen IX $\alpha 3$, an extracellular metalloprotease (Adamts10), and several inhibitors of proteinases that participate in ECM degradation: TIMP2, TIMP3, Serpina3k, and Inter- $\alpha$ trypsin inhibitor heavy chain 3.

The increased expression of these inhibitors suggests a stabilization of certain ECM components of differentiating cells. In adult rats TIMP3 is localized in the SVZ, the rostral migratory stream, and the olfactory bulb. It has been discussed as a mediator of neuronal migration by regulating axon guidance and process outgrowth (Jaworski and Fager, 2000).

\section{Gene expression changes of complement components}

Complement regulatory proteins and receptors are expressed by neurons and glial cells of the CNS (Nataf et al., 1999; Thomas et al., 2000; Yu et al., 2002; Jauneau et al., 2003). We found increased expression during neurosphere differentiation of four genes belonging to the complement cascade. These genes encode C 3 and $\mathrm{C} 4$ precursors, the $\mathrm{C} 1 \mathrm{qb}$ component, and Complement factor I precursor, which inactivates $\mathrm{C} 3 \mathrm{~b}$ and $\mathrm{C} 4 \mathrm{~b}$. $\mathrm{C} 3$ and $\mathrm{C} 4$ belong to cluster 1, which contains strongly upregulated genes.

\section{Gene expression changes related to the actin cytoskeleton}

We found many differentially expressed genes, mostly upregulated, that are involved in morphological changes expected to take place during the switch from a round neurosphere cell that is held in a floating cell ball to an adherent cell that extends cellular processes. The building and breakdown of actin filaments (actin turnover) at the cellular periphery is an indispensable event for the establishment of cellular protrusions, including the extension of dendrites and axons. Furthermore, it is important for the extension of leading edges as one mechanism of neuronal migration. Many factors control actin turnover at these structures: upstream acting key mediators including Rho family GTPases, plexins, which regulate axon guidance through these GTPases, and actin-binding and actin-remodeling proteins (Meyer and Feldman, 2002; Small et al., 2002).

A member of the Rho family GTPases, Rho7 (RhoN), and genes coding for proteins that influence GTPase activity, e.g., PlexinB3, Arhgap5, MgcRacgap, Active bcr-related gene, and Cdc42 effector protein 4 gene increased in expression, whereas Arhgap18 and $N$-chimerin decreased. Several genes the products of which directly or indirectly bind actin, some of which influence actin polymerization, were upregulated: Non-muscle $\alpha$ actinin 1, Cysteine-rich protein 1 (Crp1), Coronin actin binding protein 1C, Gelsolin (ADF/brevin), Neuronal tropomodulin (tropomodulin 2), and an EST homologous to the human actin binding LIM protein 1 and similar to Caenorhabditis elegans UNC-115. Prothymosin $\beta$ 10 transcripts decreased.

An increase in transcription was also observed for three genes encoding proteins implicated in the linkage of actin to the cell membrane: Ezrin (Villin2), Neuronal protein 4.1, and Adducin 3 (Gamma adducin). Ezrin localizes to fine, peripheral astrocytic processes but not to neurons (Derouiche and Frotscher, 2001). A function in neuronal development, however, was proposed on the basis of its localization at neuronal growth cone filopodia and perikarya in vitro (Goslin et al., 1989; Birgbauer et al., 1991; Paglini et al., 1998) and on its neuronal localization in the chick embryo (Everett and Nichol, 1990; Takahashi et al., 1999). Adducin is important for the regulation of membrane ruffling and cell motility. It localizes to dendritic spines of neurons and is associated with regions of morphogenetic cell movement in the chick embryo (Matsuoka et al., 1998; Akai and Storey, 2002).

Furthermore, four genes encoding calcium-binding proteins of the S100 family increase in expression: S100A1, S100A4, $S 100 A 6$, and $S 100 B$. Calcium-binding proteins of this family exert multiple intracellular functions (regulation of enzyme activities, modification of the actin cytoskeleton, calcium homeostasis, cell growth, and differentiation). Several of them also have extracellular functions, including regulatory effects on neural cells (for review, see Donato, 2003). All but one of the identified S100 genes (S100A6/Calcyclin) promote neurite extension as an extracellular effect. Furthermore, S100A4 regulates metastasis and is intracellularly present at the leading edge of lamellipodia where it interacts with Myosin heavy chain IIA (Kim and Helfman, 2003). $S 100 B$ is strongly expressed by astrocytes, and the secreted form also influences neuronal survival.

\section{Gene expression changes related to the tubulin cytoskeleton}

Besides the actin cytoskeleton, components of the microtubule filament system changed in expression during neurosphere differentiation. All of them were upregulated and, with one exception, changed late in our experiments (none above twofold before $48 \mathrm{hr}$ ). They include the tubulin- $\beta-I I I, \beta-4, \alpha-3 / 7$ genes and the Sperm-associated antigen 6 (Spag6). Furthermore, they encode microtubule motor proteins, the cytoplasmic dynein $2 \mathrm{~B}$ light chain, the axonemal dynein heavy polypeptide 7 , and the kinesin heavy chain member $5 \mathrm{~B}$.

SPAG6 is found in motile structures (motor cilia and flagella) that contain an axoneme ("9 + 2" structure) built from nine outer microtubule pairs and one inner microtubule pair (called the central apparatus) together with dyneins and is required for 
their structural integrity and function (Sapiro et al., 2002). Within the axoneme, SPAG6 is localized to the central apparatus. Of CNS cells, ependymal cells lining the ventricles carry multiple motor cilia. Type B SVZ astrocytes often have a single cilium with a " $9+0$ " microtubule structure. Both types of cilia extend into the lateral ventricle space (Doetsch et al., 1997, 1999). The latter structure is found in sensory cilia and in the unique motile monocilia of embryonic node cells (Brody et al., 2000).

Microtubule motor proteins fulfill a specialized function in motor cilia and flagella. In addition, these proteins mediate the transport of cargos along microtubules, including synaptic vesicle transport within axons.

\section{Gene expression changes related to cell proliferation}

Our microarray results indicate that already during the first $24 \mathrm{hr}$ after induction of differentiation, neurosphere cells cease proliferating and exit mitosis. All genes related to DNA synthesis and cell cycle progression identified in this study are contained in clusters of downregulated genes. Many fall into cluster 9, which describes the strongest decrease. Among these are Cyclins B1, D1, D2, the Cell division control protein $2(\mathrm{Cdc} 2 / \mathrm{p} 34)$, and the Cell division cycle protein 20 (Cdc20). These are important factors for cell cycle progression. We confirmed the transcript level decrease of $C d c 2 / p 34$ by semiquantitative RT-PCR (Fig. 4). The PDZbinding kinase gene, a serine/threonine kinase, was also strongly downregulated. The corresponding human protein was identified as an associated protein of the tumor suppressor hDlg and is an in vitro substrate of CDC2/Cyclin B, which is phosphorylated in a cell cycle-dependent manner (Gaudet et al., 2000). Furthermore, transcripts of genes encoding proteins involved in DNA replication decreased. These include genes for structural components of the replicating enzyme (DNA polymerase $\delta 1$, DNA polymerase $\delta$ subunit p12) as well as the DNA replication licensing factors Mcm3 and Mcm6. In addition, we found decreased expression of Chromatin assembly factor 1 subunit C (Caf-1 subunit C), Kinesin family member 23 (Kif23), Pituitary tumortransforming protein 1 (Pttg/Securin), and Fusion 1 protein (Fus1). CAF-1 is thought to mediate chromatin assembly in DNA replication by recruiting newly synthesized histones $\mathrm{H} 3$ and $\mathrm{H} 4$ to replicating DNA (Verreault et al., 1996). KIF23 is homologous to human kinesins involved in mitosis. Securin is a key regulator of sister chromatid separation during anaphase, and Fus1 is a candidate tumor suppressor gene possibly involved in G1 arrest (Kondo et al., 2001).

\section{Gene expression changes of signal transduction molecules}

Most of the large group of differentially regulated genes involved in signal transduction pathways fall into clusters that describe slight expression changes.

We found three downregulated and two upregulated genes encoding components of tyrosine kinase-mediated pathways. These are $I g f b p 2, I g f b p 4$, and Cnil (downregulated), and Igfbp5 and Ptpns1 (Shps-1) (upregulated). The expression change of Ig$f b p 2$ was confirmed by semiquantitative RT-PCR (Fig. 4). The $I g f b p$ genes are exceptional for the signal transduction category because they fall into clusters 1 and 9 of strongest and earliest expression change. Of all 454 clones with relevant (more than twofold) changes in both series, those representing the Igfbp2 gene show the highest fold changes in our study: up to 25.79-fold decrease in transcript level. A dramatic decrease is especially seen between 24 and $48 \mathrm{hr}$. In addition to $\operatorname{Igfbp} 2, \operatorname{Igfbp} 4$ is strongly downregulated. Both IGF-binding proteins inhibit IGF actions. $I g f b p 5$, on the other hand, increases in expression and is known to

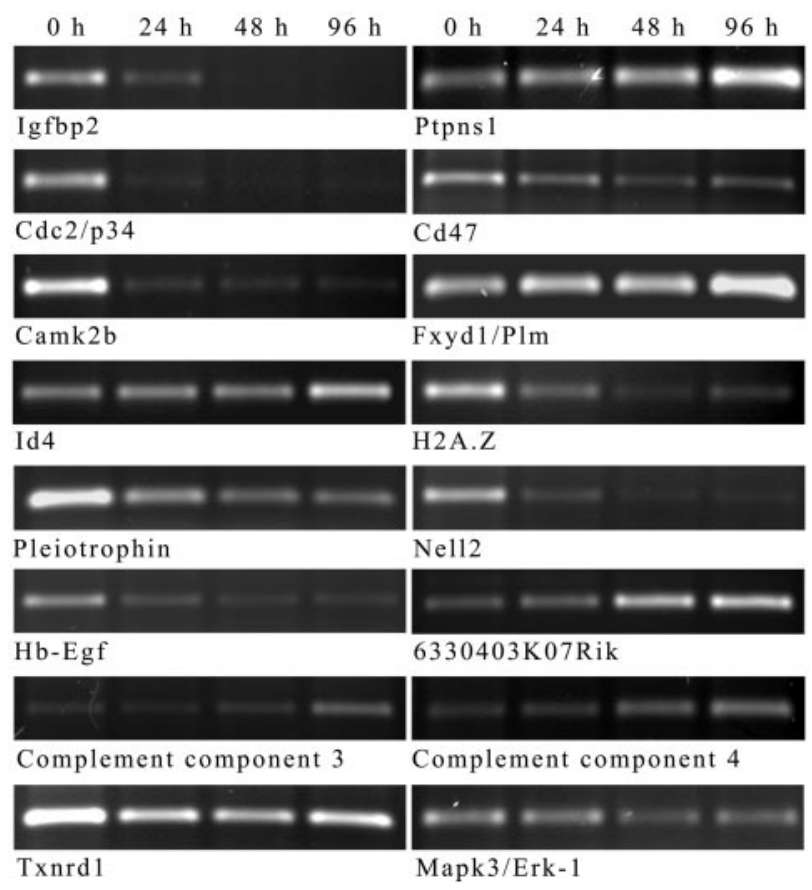

Figure 4. Semiquantitative RT-PCR analysis of selected genes. Relative gene expression levels before and after induction of differentiation are shown. The respective transcripts were upregulated or downregulated as expected from the microarray results. Expression of Txrnd1 and Mapk3/Erk-1 was used as a reference.

potentiate IGF-I effects. Thus, differentiating cells are apparently converted into an IGF-responsive state. IGF-I stimulates neurogenesis, oligodendrogenesis, synaptogenesis, and cell migration, and it inhibits apoptosis (D'Ercole et al., 2002; Hsieh et al., 2004). In addition, IGFBP5 can exert IGF-independent effects and has also been found in the nucleus (for review, see Firth and Baxter, 2002; Mohan and Baylink, 2002).

Ptpns1 (Shps-1/Sirpo/Bit/Mfr/p84 neural adhesion molecule) encodes a transmembrane protein, which acts as an important regulator of IGF-I signaling (Clemmons and Maile, 2003). Our microarray study revealed an expression increase of Ptpns1 (Shps-1) already at $24 \mathrm{hr}$ and even more at 48 and $96 \mathrm{hr}$. This result was confirmed by semiquantitative RT-PCR (Fig. 4).

The PTPNS1 (SHPS-1) ligand gene Cd47 [Integrin-associated protein $(I A P)]$, which also encodes a transmembrane protein, slightly decreased in expression (Fig. 4). Immunostainings of neurospheres revealed that both the CD47 and PTPNS1 (SHPS-1) protein are synthesized by undifferentiated neurosphere cells that form tight cellular clusters (Fig. 2). After differentiation, PTPNS1 (SHPS-1) is still present in the sphere, but is also synthesized by cells that have dissociated from the sphere and surround the compact cell cluster. Cells that have migrated farther away do not stain with the anti-PTPNS1 (SHPS-1) antibody. In addition to the signal of compact neurosphere cells, we detected a faint CD47 staining of single cells that had migrated away from the sphere. In our in vitro system, cells migrate as single cells. In vivo, however, rodent neuroblast cells migrate as packed chains with tight cell-cell contacts. Using an in vitro chain migration assay of neurosphere cells by plating them in Matrigel (Wichterle et al., 1997), we demonstrated that cells migrating in chains synthesized CD47 as detected by immunofluorescence staining (Fig. 5a). Migrating cells also showed PTPNS1 (SHPS-1) immunoreactivity (Fig. 5b,c), albeit less intensely so than CD47.

Adult sagittal brain sections immunoreacted with PTPNS1 
(SHPS-1), and CD47 antibodies revealed a band of intense staining immediately underlying the less intensely stained SVZ (Fig. $6 a-d$, arrowheads). Weaker signals were detected in what appeared to be the cytoplasm of GFAP-positive astrocytes (Fig. $6 a, b$, arrows), and of HUC/D-positive neuroblasts (Fig. $6 c, d$, arrows). In the RMS, GFAP staining partially overlapped with that of PTPNS1 and CD47 (Fig. 6e,f, arrows), which was also the case for PSA-NCAM with CD47 and PTPNS1, respectively (Fig. $6 g, h$, arrows)

Four genes coding for factors involved in G-protein-linked pathways increase in expression: Edg3, Neurotensin receptor 2, Rgs2, and Rgs16. Edg3 (Endothelial differentiation gene $3 / S 1 p_{3}$ ), a widely expressed G-protein-coupled receptor for the sphin-
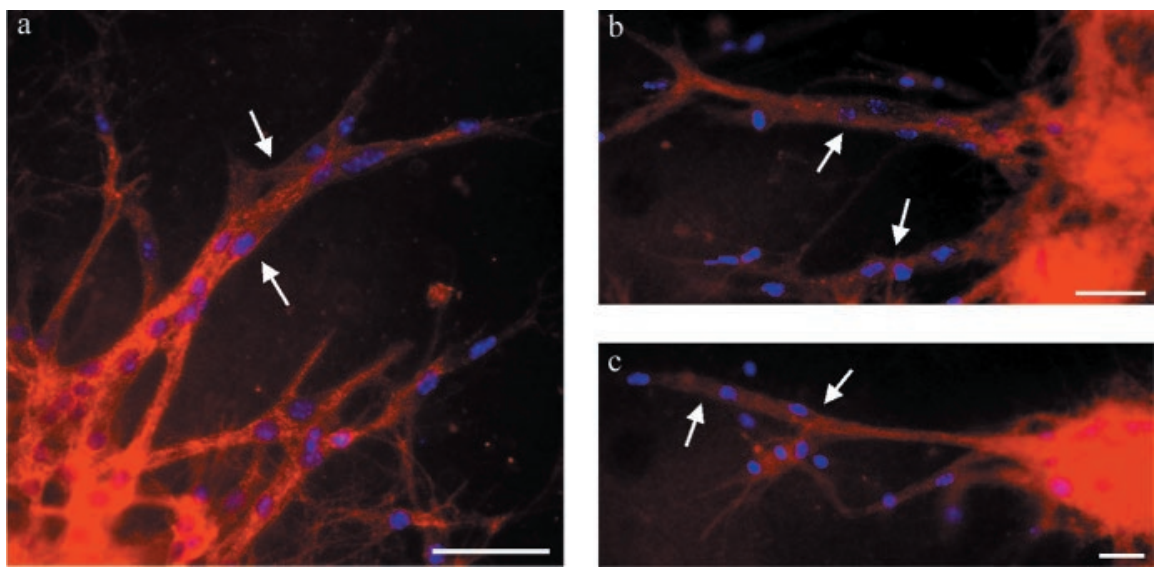

Figure 5. Immunolocalization of CD47 ( $a$, red signals) and PTPNS1 ( $b, c$, red signals) in differentiating neurosphere cells that were embedded in Matrigel. Blue signals indicate DAPI-stained nuclei. Cellular chains are indicated by arrows. Scale bars, $50 \mu \mathrm{m}$. golipid Sphingosine-1-phosphate (S1P), was upregulated in the course of neurosphere differentiation. EDG3 is coupled to ERK/MAPK (extracellular signal-related kinase/mitogen-activated protein kinase), RHO (ras homolog), and RAC (ras-related C3 botulinum toxin substrate), Ca mobilization, transcription factors, and serum response factor (An et al., 2000). Of special interest for our study is the finding of EDG3mediated induction of membrane ruffling, activation of RAC, and chemotaxis toward S1P (Kon et al., 1999; Wang et al., 1999; Okamoto et al., 2000). The ligand of Neurotensin receptor 2 has various functions in the CNS (Tyler-McMahon et al., 2000). On the cellular level, Neurotensin can lead to tyrosine phosphorylation of the focal adhesion kinase, a protein that localizes to integrin clusters and influences cell migration, adhesion, survival, and proliferation (Leyton et al., 2002).

Differentially expressed downstream components of the inositol phospholipid pathway were also found: Pten-induced kinase, $P L C \delta$, and Cdp-diacylglycerol synthase increased and $P k c \beta$ decreased.

Two genes, cGMP-stimulated phosphodiesterase $2 A$ and Darpp-32, both involved in cyclic monophosphate signaling, decreased.

We found three differentially expressed genes that belong to calcium-dependent signal transduction cascades: Calmodulin was upregulated, whereas the Calcium/Calmodulin-dependent protein kinase II $\beta$ and the catalytic subunit of the Calmodulin-regulated protein phosphatase-2B (Calcineurin) decreased. Camk $2 b$ is striking because it belongs to cluster 9 of early and very strongly downregulated genes. We confirmed its transcript level change by semiquantitative RT-PCR (Fig. 4).

Two genes implicated in the thyroid hormone system changed their expression: Deiodinase iodothyronine type II (D2) was downregulated, and Thyroid hormone receptor interactor 6 (Trip6) increased. Deiodinase iodothyronine type II (D2) catalyzes the conversion of T4 into the active form of thyroid hormone, T3. In the brain, $\sim 80 \%$ of $\mathrm{T} 3$ is generated locally from $\mathrm{T} 4$ by the action of D2. This enzyme is expressed by glial cells in normothyroid postnatal rats (Guadano-Ferraz et al., 1999). The effects of T3 in the brain are diverse and include neuronal differentiation, migration, neurite outgrowth, synapse formation, and oligodendrocyte differentiation and myelination. Astrocytes treated with T3 secrete growth factors, including EGF, that in turn act on neurons (Bernal and Nunez, 1995; Gomes et al., 2001a,b; Lima et al., 2001; Forrest et al., 2002; Konig and Moura Neto, 2002; Martinez and Gomes, 2002).
Genes involved in the NF- $\kappa \mathrm{B}$-dependent signaling pathway were also noticeable: Tnfrsf 21 and NF- $\kappa \mathrm{B}$ target gene Ier 3 transcripts decrease and levels of the Tnf receptor-associated factor 1 increase. In line with its designation, the immediate early gene Ier3 is contained in cluster 6, which represents slight but early expression changes (between time point 0 and $24 \mathrm{hr}$ ). Deltex 1 , a component of the Notch signaling pathway, increased slightly. The Notch signaling pathway is fundamental in cell-fate determination, including the development of neural progenitor cells into neurons and glial cells. Cytoplasmic Deltex proteins are positive regulators of this pathway that act independently of the Notch cascade, which involves RBP-J (recombining binding protein suppressor of hairless) and Hes proteins. Previous reports implicate the Notch pathway in astroglial versus neuronal cell-fate determination (Tanigaki et al., 2001); however, a recent publication demonstrates its function in the maintenance of neural stem cells (Hitoshi et al., 2002). Mammalian Deltexl has been shown to act as a negative modulator of Notch1 signals (Sestan et al., 1999; Izon et al., 2002). It interacts with the intracellular domain of Notch 1 and inhibits the action of neurogenic basic helix-loophelix (bHLH) transcription factors Mash1 and E2A (Matsuno et al., 1998; Kishi et al., 2001; Yamamoto et al., 2001). Overexpressed Deltex1 inhibits neural progenitor cell differentiation and opposes the effect of Notch 1 on neurite outgrowth (Sestan et al., 1999; Yamamoto et al., 2001). A Notch/Deltex1 signaling pathway that involves F3/contactin promotes oligodendrocyte maturation and myelination (Hu et al., 2003). Murine Deltex1 is expressed in the embryonic neuroepithelium. In later developmental stages its expression is restricted to postmitotic differentiating neurons and absent from the proliferative ventricular zone (Mitsiadis et al., 2001).

Finally, the Latent transforming growth factor- $\beta$ binding protein (Ltbp) $4 S$, implicated in the $\operatorname{Tgf} \beta$ pathway, was upregulated.

\section{Gene expression changes related to neural progenitors}

We identified three growth factor encoding genes, all of which were downregulated during differentiation: Hb-Egf (Heparinbinding EGF-like growth factor/Diphtheria toxin receptor), Pleiotrophin (Heparin-binding growth-associated molecule/HbGam), and Nell2 (Neural epidermal growth factor-like-like 2). Thus, they are expressed by neural progenitor cells. The transcriptional changes of these genes were confirmed by semiquantitative RT-PCR (Fig. 4). The Pleiotrophin receptor gene Syndecan-3 also decreased in expression. In addition, we found a 

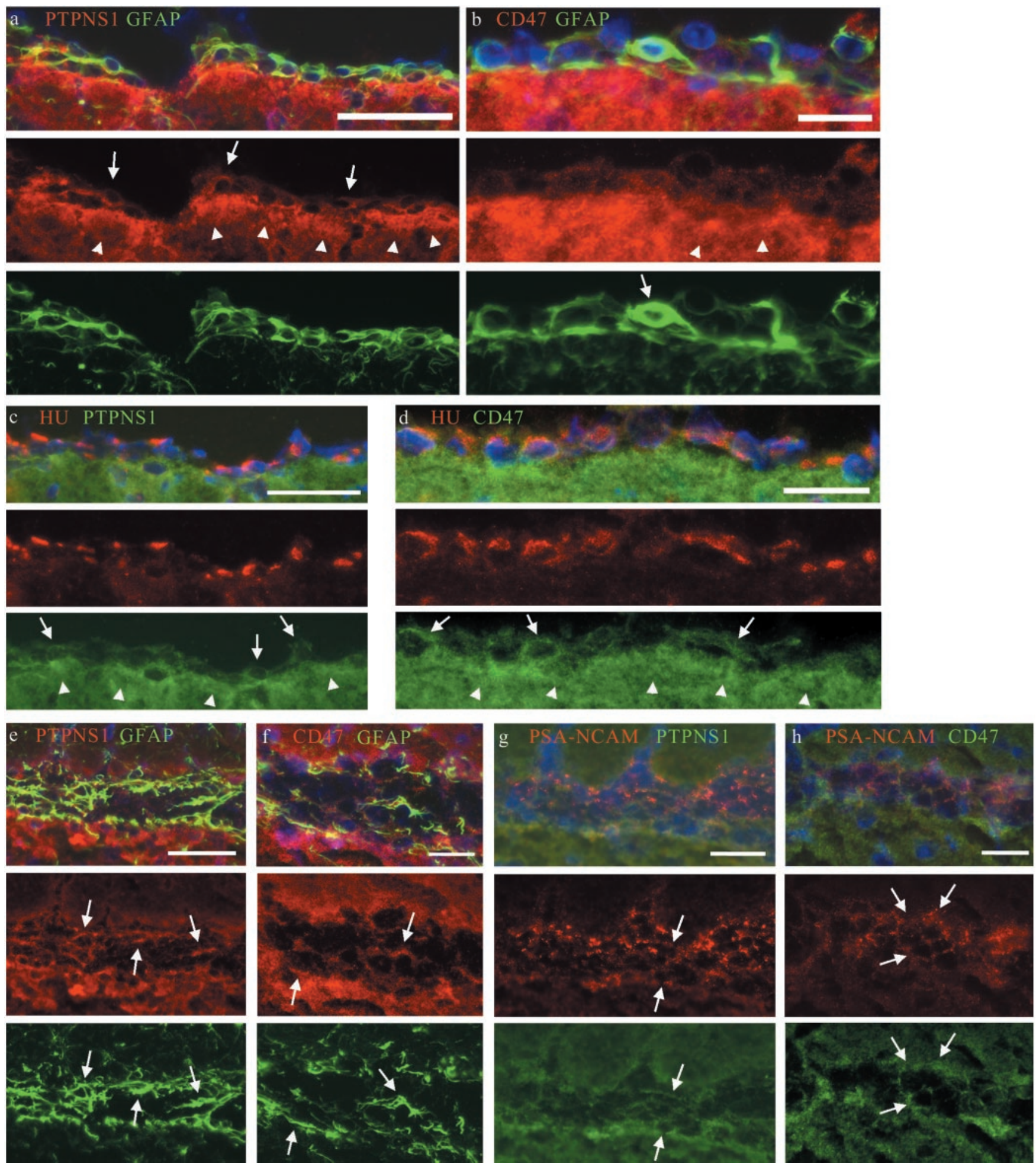

Figure 6. Localization of PTPNS1 $(a, c, e, g)$ and CD47 $(b, d, f, h)$ on sagittal adult brain sections as determined by immunofluorescence microscopy. Regions of the lateral ventricle wall ( $a-d)$ and the RMS (e-h) are shown. Coimmunostainings with GFAP ( $a, b, e, f$, green signals), HUC/D (c, $d$, red signals), and PSA-NCAM ( $g, h$, red signals) were performed. $c, d, g, h$, PTPNS1 and CD47 signals are shown in green. $a, b, e, f$, PTPNS1 and CD47 signals are shown in red. Note the band-like PTPNS1 and CD47 staining pattern ( $a-d$, arrowheads). Examples of cells positive for GFAP and PTPNS1 ( $a$ ) or GFAP and CD47 (b) are marked by arrows. c, d, Arrows depict examples of cells positive for PTPNS1 and HUC/D ( $c$ ) or CD47 and HUC/D ( $d$ ). e- $h$, Arrows indicate an overlapping staining pattern of PTPNS1 and GFAP ( $e$ ), CD47 and GFAP ( $f$ ), PTPNS1 and PSA-NCAM ( $(c)$ as well as CD47 and PSA-NCAM ( $h$ ). Scale bars: $a, e, 100 \mu \mathrm{m} ; b-d, f, h, 50 \mu \mathrm{m}$.

downregulation of the gene encoding brain fatty acid-binding protein (FABP7/BFABP/BLBP), a brain-specific member of the FABP family of cytosolic proteins that bind fatty acids, eicosanoids, and retinoids. FABP7 is characteristic for radial glial cells.
Immunostainings of neurosphere cells revealed that Pleiotrophin was restricted to compact cells in the center of the neurosphere and disappeared as cells dissociated from the sphere and differentiated (Fig. 2). In the rostral migratory stream, cytoplasmic Pleiotrophin immunoreactivity was associated with small 

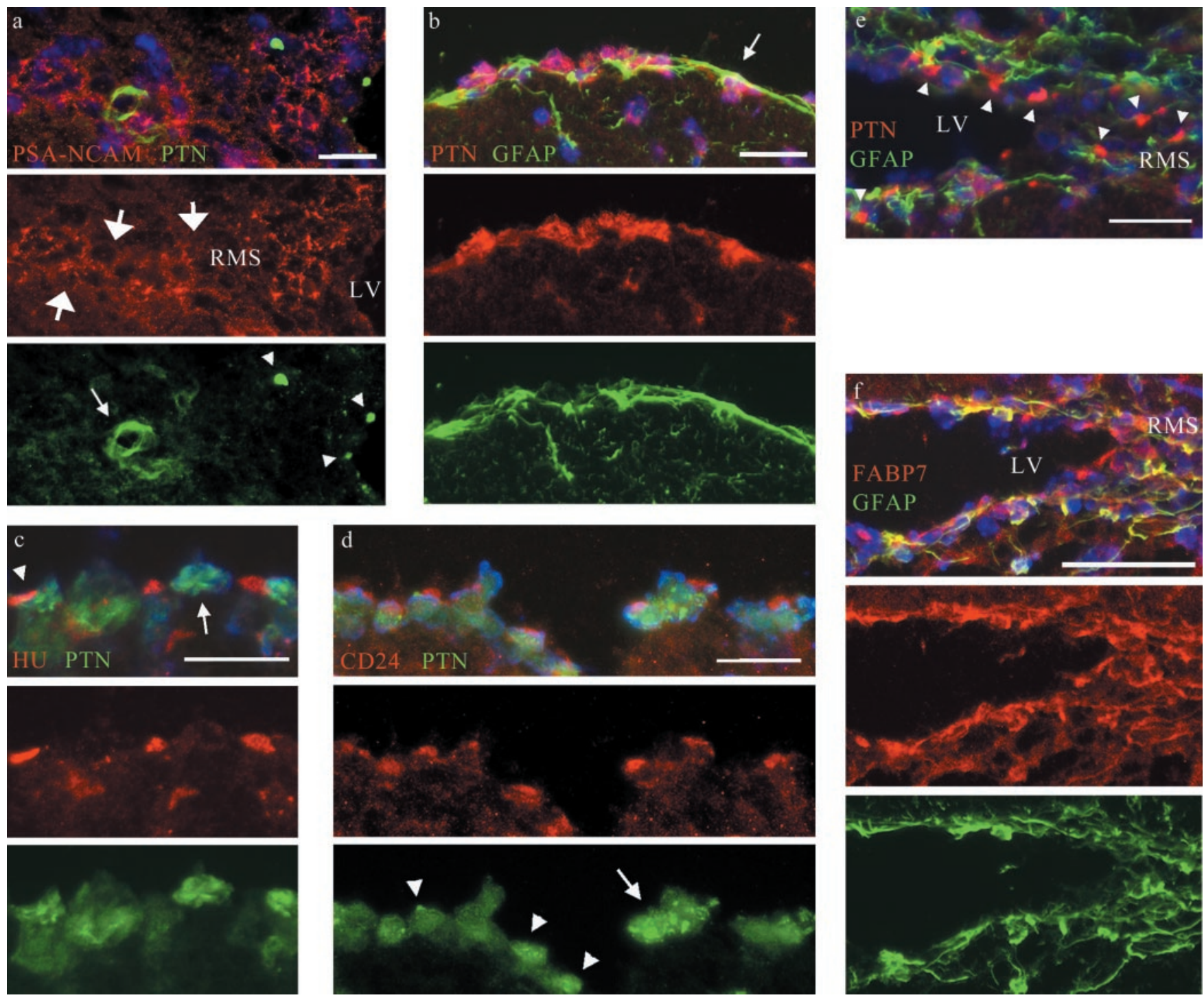

Figure 7. Localization of Pleiotrophin ( $a-e)$ and FABP7 ( $f$ ) on sagittal adult brain sections as determined by immunofluorescence microscopy. A nuclear staining of the Pleiotrophin antibody can be seen in cells of the lateral ventricle wall ( $b$, red signal; $c, d$, green signals). $b$, Green signals indicate GFAP. $c$, Red signals indicate HUC/D. $d$, Red signals indicate CD24. $b$, Arrow points at a GFAP-positive cell.c, Arrow points at an HUC/D-negative cell. a, e, Arrowheads point at a spot-like Pleiotrophin pattern. $a$, Green signals indicate Pleiotrophin; red signals indicate PSA-NCAM.e, Green signals indicate GFAP; red signals indicate Pleiotrophin. In the RMS, the Pleiotrophin antibody stains small vessels $(a$, single small arrow pointing at green signals). $a$, Thick arrows indicate PSA-NCAM-positive cells in the RMS.f, Colocalization of FABP7 (red) and GFAP (green) in the SVZ and RMS. a-f, Blue signals indicate DAPI-stained nuclei. LV, Lateral ventricle; RMS, rostral migratory stream. Scale bars, $50 \mu \mathrm{m}$.

vessels (Fig. 7a, thin arrow) as has been described previously (Yeh et al., 1998), but not with PSA-NCAM-positive neuroblasts (Fig. $7 a)$. In the subventricular zone lining the walls of the lateral ventricles, we found evidence for cellular colocalization of Pleiotrophin with the neuronal marker HUC/D (Fig. $7 c$, arrowhead) and CD24 (Fig. 7d), which is present in ependymal cells and type A neuroblasts (Calaora et al., 1996). Pleiotrophin immunoreactivity was also co-detected in the same cellular SVZ layer as the glial marker GFAP (Fig. 7b), but because of the tight association of the glial processes with neuroblasts and ependymal cells in this layer, only electron microscopic analysis can unambiguously ascertain whether Pleiotrophin is expressed by glial cells. Nuclear Pleiotrophin staining in the superior-posterior ventricle wall (Fig. $7 b-d$ ) was mostly punctate (Fig. $7 d$, arrow), whereas more homogeneous nuclear staining was characteristically seen in other regions of the SVZ. Pleiotrophin has previously been shown to bind to nucleolin, a major nucleolar protein, which functions as a shuttle protein between the nucleus and cytoplasm (Take et al., 1994). In addition, we consistently found distinct Pleiotrophin-positive spots in the anterior wall abutting the striatum, the most anterior portion of the superior ventricle wall, as well as in its rostral extension (Fig. $7 a$,e, arrowheads). These spots appeared cytosolic and were difficult to assign to specific cell types.

Pleiotrophin exerts many different cellular effects. In the context of our report, some are of special interest (Li et al., 1990; for review, see Deuel et al., 2002; Muramatsu 2002). It stimulates the migration of embryonic neurons, is present in radial glial processes, and localizes along neuronal migration routes (Matsumoto et al., 1994; Rauvala et al., 1994; Wewetzer et al., 1995; Nolo et al., 1996; Silos-Santiago et al., 1996; Kinnunen et al., 1998, 1999; Maeda and Noda, 1998). The migratory effect is mediated through the binding of Pleiotrophin to the transmembrane protein-tyrosine phosphatase PTP $\zeta$ on migrating neurons (Maeda and Noda, 1998). Furthermore, it promotes neurite out- 
growth, likely mediated through another receptor, Syndecan-3 (Raulo et al., 1994). Syndecan-3 is a transmembrane proteoglycan that binds to extracellular ligands and regulates signaling and cytoskeletal organization during developmental processes. It is localized to axons in the developing brain and to oligodendrocyte progenitors (Kinnunen et al., 1998; Hsueh and Sheng, 1999; Winkler et al., 2002) (for review, see Rapraeger, 2001).

Antibodies against FABP7 stain the neurosphere as well as the cell body and cellular processes of differentiating cells close to the cell cluster (Fig. 2). In the brain, FABP7 was found in the SVZ and along the RMS. The FABP signals coincided entirely with the GFAP staining, which strongly suggests that SVZ astrocytes synthesize FABP7 (Fig. $7 f$ ). Because the monoclonal GFAP antibody that we used is known to specifically recognize type B cells (neurogenic astrocytes) but not type $C$ cells (transit-amplifying cells) (Doetsch et al., 2002), we conclude that FABP7 is expressed by type B cells.

FABPs are believed to play a role in the cellular solubilization, transport, and metabolism of their ligands, and the spatiotemporal production of mouse Fabp7 mRNA and protein correlates with differentiation of neuronal and glial cells (Feng et al., 1994; Kurtz et al., 1994). At embryonic day 10 (E10), it is expressed in the CNS columnar neuroepithelium, and from E12 to E14 becomes enriched in radial glial cell bodies at the ventricular surface, which extend FABP7-positive radial processes through the ventricular wall to the pial surface. This expression parallels the appearance of a broad layer of MAP2-positive neuronal cells in the intermediate zone of the ventricular wall. At later stages, FABP7 is no longer present in the ventricular zone; it is restricted to cells attached to the pial surface. This change in expression reflects a transition from radial glial cells to astrocytes. In the adult CNS, FABP7 has been detected in Bergmann glial cells of the cerebellum, in radial glial cells spanning the granule cell layer of the hippocampus, in the glia limitans, and in some astrocytes throughout the CNS. The application of anti-FABP7 antibodies to primary cell cultures led to an inhibition of glial and neuronal differentiation but did not show any effect on cell proliferation or adhesion (Feng et al., 1994).

$H b$-Egf had transcriptional changes characteristic of cluster 6, with the strongest downregulation occurring at $48 \mathrm{hr}$. HB-EGF exists as a membrane-bound form (proHB-EGF) that is growth inhibitory. Through ectodomain shedding, a secreted form (sHB-EGF) is generated. The secreted form acts as a mitogen for multipotent neural progenitor cells in vitro as well as in vivo, particularly within the SVZ, and enhances neuronal survival (Kornblum et al., 1999; Caric et al., 2001; Jin et al., 2002, 2003). In situ hybridization studies on the expression of $\mathrm{Hb}$-Egf in postnatal brain are contradictory. Nakagawa et al. (1998) found high levels within proliferative regions including the subventricular zone; Kornblum et al. (1999) did not. Caric et al. (2001) reported $\mathrm{Hb}$-Egf expression in several migration pathways within the CNS.

Nell2 belongs to cluster 10, showing steadily increasing downregulation with time. It encodes a glycoprotein found in the rough endoplasmic reticulum and is secreted into the extracellular space (Kuroda et al., 1999). Immunocytochemical studies revealed its presence in brain, but not in peripheral tissues, and expression by neurons, but not by glial cells. NELL2 protein is abundant in the hippocampus and cerebral cortex, and moderate levels are found in the olfactory bulb (Oyasu et al., 2000). In the embryonic rat, Nell 2 mRNA is detected in ventricular and differentiating zone of the spinal cord, medulla, and pons (Kim et al., 2002). In chick embryos, transcripts are found in the spinal cord ventricular zone and differentiating areas, whereas in the CNS
Nell2 mRNA is restricted to postmitotic neurons as they start differentiation (Nelson et al., 2002).

\section{Gene expression changes of chromatin-associated components and transcription factors}

The change of an undifferentiated progenitor cell to a specialized cell type requires switches in gene expression that alter the pattern of inactive and active genes of these two cellular states. This switch in gene expression involves changes of chromatin states that differ in the accessibility of genomic DNA regions for transcription regulatory factors. In addition, the expression of individual transcription factors that positively or negatively control certain target genes is involved in this process. Strikingly, all downregulated genes in this category fall into clusters 6 and 10, with the exception of Fosb in the NT4 experiment. Both of these clusters represent the slightest gene expression changes of our study. Within cluster 6 , genes decrease the most from time point 0 to $24 \mathrm{hr}$; genes of cluster 10 show a continuous downregulation over time. In parallel, most of the upregulated genes in this category are found in cluster 4 , which describes slight alterations with the highest change between time point 0 and $24 \mathrm{hr}$. Exceptions are Id4 and Meiosis expressed gene 1; both fall into cluster 1, which contains the strongest upregulated genes.

Among the differentially expressed genes encoding chromatin and chromatin-associated proteins Histone $2 \mathrm{Az}$ (H2A.Z), Histone $2 A x(H 2 A . X)$, the high mobility group gene Hmgb2 (formerly Hmg2), and Thymopoietin (Lap2) were downregulated, whereas transcript levels of Histone $2 B$ increased. The downregulation of Histone $2 \mathrm{Az}$ was confirmed by semiquantitative RT-PCR (Fig. 4).

Among the transcription factors with relevant expression changes were five that decreased in expression. Three of these, Transcription factor 12 (Htf4/Heb/Reb), Stra13 (bHlhb2/Clast5/ Sharp2/Dec1), and Olig2, belong to the helix-loop-helix class. Furthermore, we found a downregulation of Etv5 (Erm) that belongs to the PEA3 group of transcription factors, Fosb, and $Y b-1$.

Increasing mRNA levels of eight transcription factors were identified. These include four genes encoding zinc finger proteins related to transcription: the RIKEN cDNA 3110024A21 gene, ENSMUSG00000013419, and genes encoding ZDHHC9, and DAN (neuroblastoma suppressor of tumorigenicity 1, N03). Furthermore, the bHLH-leucine zipper transcription factor Srebp-1, Id4, a negative regulator of HLH transcription factors, an EST similar to the human p66 $\alpha$ encoding gene, and the forkhead transcriptional activator Foxj1 (Hfh-4/Fkhl13/Hnf-3) were upregulated. The transcript level increase of $I d 4$ was confirmed by semiquantitative RT-PCR. Finally, we found a distinct increase in the Meiosis expressed gene 1 expression. Its product associates specifically with meiotic chromosomes (Steiner et al., 1999); the relevance with respect to neural differentiation is unclear.

Our finding of an altered expression of $H 2 A$.X has to be looked at with caution, because the coding sequence of this gene differs only slightly from the $10 H 2 A 1$ and the single $H 2 A 2$ variants, in contrast to $H 2 A . Z$, which differs considerably. Therefore, a cross-hybridization of $H 2 A 1, H 2 A 2$, and $H 2 A$. X transcripts can occur.

$\mathrm{Hmgb2}$ is widely expressed during embryogenesis but exhibits tissue-restricted expression in the adult (Ronfani et al., 2001). Of note is its localization to the SVZ and intermediate zone at E17 but reported absence in the adult brain. Blockage of Hmgb2 expression with antisense oligonucleotides inhibits cell division (Yamazaki et al., 1995).

$\mathrm{Htf} 4$ belongs to the E-protein family of bHLH transcription factors that are widely expressed (Zhang et al., 1995) and de- 
creases during neural differentiation (Klein et al., 1993; Neuman et al., 1993). Stra13 belongs to a distinct bHLH class similar to the Hes class. Its product acts as a transcriptional repressor at E-box sequence elements and promotes neuronal but inhibits mesodermal and endodermal differentiation (Boudjelal et al., 1997; Sun and Taneja, 2000; St. Pierre et al., 2002). Olig2 is a transcription factor that acts as a key mediator of oligodendrocyte specification. It is important for the self-renewal of cultured neurosphere cells and their differentiation into neurons and oligodendrocytes (Hack et al., 2004). Oligodendrocyte precursors, differentiated oligodendrocytes, and also neural progenitor cells express Olig2 (Lu et al., 2000; Takebayashi et al., 2000; Zhou et al., 2000; TekkiKessaris et al., 2001; Karsten et al., 2003).

Inhibitor of DNA binding proteins act through the formation of heterodimers with E-protein bHLH factors, thereby sequestering them from bHLH factors that require E-proteins such as members of the Mash, Neurogenin, NeuroD, and Olig family (Norton, 2000). In this way, they inhibit the differentiation of progenitor cells into neurons and oligodendrocytes. Of interest is also the elevated transcript level of an EST similar to the human p66 $\alpha$ encoding gene. The latter belongs to a new family of potent transcriptional repressors interacting with the methyl-CpGbinding proteins MBD2 and MBD3 (Brackertz et al., 2002).

In the context of our findings concerning genes for motor cilia and flagella components (see Gene expression changes related to the tubulin cytoskeleton), the slight upregulation of the forkhead transcriptional activator Foxj1 is of special interest. Foxj1 is expressed in tissues containing cells with motor cilia and flagella such as testis, oviduct, lung, and brain (Clevidence et al., 1993; Hackett et al., 1995; Lim et al., 1997; Murphy et al., 1997). It is present in motor cilia and flagella as well as in the unique motile monocilium of the embryonic node, but not in sensory cilia (Brody et al., 2000). The failure of directed left-right determination in Foxj1 (Hfh-4) null mice, which is normally regulated by embryonic node cells, indicates a Foxj1 ( $H f h-4)$-based defect of their motile monocilium (Brody et al., 2000).

Erm is expressed in various tissues at different developmental stages (Chotteau-Lelievre et al., 1997). Erm expression becomes restricted to cells lining the ventricles rather than differentiating cells of the neural wall as neural development proceeds.

\section{Gene expression changes related to metabolism}

Some of the genes with differential expression encode proteins involved in cellular metabolism. The downregulated genes were found in clusters 6 and 10 describing very slight expression changes. With the exception of Nat-1, none of the upregulated genes belongs to cluster 1, which contains strongly and very early increasing transcripts. Most of the genes of this category are related to glucose and energy metabolism, for example, Lactate dehydrogenase, Glucose-6-phosphate dehydrogenase, Phosphoglycerate dehydrogenase, and Brain glycogen phosphorylase. The latter is present in astrocytes and ependymal cells, but rarely found in neurons of the rat brain (Pfeiffer-Guglielmi et al., 2003).

Other differentially regulated genes identified are involved in amino acid transport ( $N$ system amino acids transporter Nat-1), carbon dioxide transport and acid-base balance (Carbonic anhydrase 2 and 14), and nucleic acid metabolism (Thymidine kinase 1, Dutpase). Thymidine kinase 1 is known to be present in proliferating cells with a peak in S phase. It is low in resting cells, which is in line with the decreased proliferation in our differentiation culture (see Gene expression changes related to cell proliferation).

An interesting gene that was downregulated is Phosphoglucose isomerase 1 (Gpi1). GPI1 plays a central role in both glycolysis and gluconeogenesis; however, it is also known as Autocrine motility factor or Neuroleukin and seems to fulfill several functions. Purified Neuroleukin from Bacillus stearothermophilus promotes neurite outgrowth of rat EGF-responsive neural embryonic progenitor cells (Sun et al., 1999).

Several genes coding for enzymes involved in steroid metabolism were also identified, all of them with increasing expression levels: UDP-glucuronosyltransferase 1, Oxysterol binding protein 2, Prostaglandin D2 synthase, the Leukotriene B4 $\omega$-hydroxylase (CYP4F14), and Retinal short-chain dehydrogenase/reductase 2.

\section{Gene expression changes related to ion channels, transporters, and lipoproteins}

In addition, some genes encoding ion channels, transporters, and lipoproteins were differentially regulated, most of them upregulated. An exception was the Fxyd1 gene, which belongs to cluster 1 (strongly and very early increasing genes). It encodes a regulator of the Na,K-ATPase (Crambert and Geering, 2003). The GABA-A receptor $\alpha-5$ subunit slightly increased, but only by $96 \mathrm{hr}$. Increasing transcripts of the genes $\mathrm{Na}, \mathrm{K}$ transporting ATPase subunit $\alpha$, the Abca3 transporter, and the Monocarboxylate transporter 1 were also detected. Of the genes related to lipoproteins, Lipid transfer protein II (Pltp) expression increases. PLTP is an important regulator of plasma high-density lipoprotein (HDL) levels and HDL particle distribution and is secreted by neurons, microglia, and astrocytes (Vuletic et al., 2003).

A slight and late increase is also noted for the gene encoding sorLA/LR11, a protein with features typical for low density lipoprotein receptor family and the Vps10p domain receptor family, which is present in neurons (Jacobsen et al., 1996; Motoi et al., 1999). On the other hand, transcript levels of Scavenger receptor class B1, encoding a lysosomal membrane protein that can bind HDL, decrease. Finally, gene expression of the Apolipoprotein J increases.

\section{Discussion}

The transition of multipotent neural progenitor cells into differentiated neuronal and glial cells involves complex gene expression changes of which only few are known to date.

To learn more about very early and probably decisive transcriptional changes, we compared the gene expression of undifferentiated neurosphere cells from the SVZ of P7 mice with cells at 24, 48, and $96 \mathrm{hr}$ after induction of differentiation using BDNF or NT4. This time course allows us to ascertain the onset of transcriptional changes and follow subsequent alterations. Previously, neurosphere cells have only been compared with one cellular state after induction of differentiation using large scale expression methods. Geschwind et al. (2001) investigated undifferentiated neurosphere cells from P0 mouse cortex and cells differentiated for $24 \mathrm{hr}$ using a combination of representational difference analysis and microarrays. Karsten et al. (2003) compared progenitor cells from prenatal day 1 and cells that were differentiated for $24 \mathrm{hr}$. Easterday et al. (2003) compared P1 cortical neuropheres differentiated for $24 \mathrm{hr}$ with three different undifferentiated neurosphere populations from mice. Cells derived from the striatum of rat embryos were used in two other differentiation studies by Zhou et al. (2001) and Wen et al. (2002).

We have provided detailed information on many genes in Results. Our discussion therefore covers selected new and important aspects. Almost all of the differentially expressed genes showed consistent upregulation or downregulation throughout 
Table 2. Comparison of in vitro and in vivo findings

\begin{tabular}{|c|c|c|c|}
\hline $\begin{array}{l}\text { In vitro differentiation steps of neuro- } \\
\text { sphere cells }\end{array}$ & In vitro gene expression changes & Adult SVZ and RMS compartment & Similarities and differences \\
\hline Cessation of proliferation & $\begin{array}{l}\text { All genes involved in DNA replication and cell } \\
\text { cycle progression are downregulated (see } \\
\text { Table 1) }\end{array}$ & $\begin{array}{l}\text { Type B and ( cells are dividing cells. Neuroblasts } \\
\text { (type A cells) divide as they migrate along } \\
\text { the RMS. They exit the cell cycle after differ- } \\
\text { entiation. }\end{array}$ & Different timing of cell cycle exit \\
\hline $\begin{array}{l}\text { Attachment of neurosphere cells to } \\
\text { poly-L-lysine }\end{array}$ & $\begin{array}{l}\text { Extracellular matrix components are upregu- } \\
\text { lated and downregulated (e.g. Tenascin C; } \\
\text { see Table 1) }\end{array}$ & $\begin{array}{l}\text { All SVZ cell types make contact with the extra- } \\
\text { cellular matrix. Changes among the three } \\
\text { compartments (SVZ, RMS, OB) are likely to } \\
\text { involve ECM components. }\end{array}$ & $\begin{array}{l}\text { Tenascin C is present in the SVZ, RMS, } \\
\text { and olfactory bulb }\end{array}$ \\
\hline $\begin{array}{l}\text { Detachment of cells from the neuro- } \\
\text { sphere cell cluster }\end{array}$ & $\begin{array}{l}\text { Genes encoding cell-cell adhesion molecules } \\
\text { that are downregulated (see Table 1). Ptpns1 } \\
\text { and }(d 47, \text { which regulate cell aggregation, } \\
\text { are differentially expressed. }\end{array}$ & $\begin{array}{l}\text { All cell types in the SVZ and RMS are tightly } \\
\text { packed and form many cell-cell contacts. } \\
\text { Cells detach from the SVZ niche on entry into } \\
\text { the RMS. Within the RMS, neuroblasts mi- } \\
\text { grate in homotypic cellular chains. In the } \\
\text { olfactory bulb, they lose these cellular con- } \\
\text { tacts and migrate as individual cells. }\end{array}$ & $\begin{array}{l}\text { Similar cell-cell adhesion systems } \\
\text { are likely used: proteins synthe- } \\
\text { sized by the cells in vitro are also } \\
\text { found in the SVZ in vivo (our im- } \\
\text { munostainings of brain sections) }\end{array}$ \\
\hline $\begin{array}{l}\text { Cellular migration away from the cell } \\
\text { cluster. On poly-L-lysine, cells mi- } \\
\text { grated as single cells; in Matrigel, } \\
\text { chain migration was observed. }\end{array}$ & $\begin{array}{l}\text { Genes involved in actin cytoskeleton turnover } \\
\text { are important for leading edge extension in } \\
\text { migrating cells (see Table 1), Ptpns1 and } \\
\text { (d47, which have been previously shown to } \\
\text { regulate cell migration. }\end{array}$ & $\begin{array}{l}\text { Within the RMS, neuroblasts migrate in cellular } \\
\text { chains; in the olfactory bulb, they migrate as } \\
\text { individual cells. }\end{array}$ & Similar modes of cell migration \\
\hline $\begin{array}{l}\text { Differentiation into astrocytes, neurons, } \\
\text { and oligodendrocytes }\end{array}$ & $\begin{array}{l}\text { Transcription factors, which are key regulators of } \\
\text { cell-type specification and lineage restriction } \\
\text { (see Table 1). Several cell type-specific genes } \\
\text { are upregulated (see Results). }\end{array}$ & $\begin{array}{l}\text { Type B cells give rise to type C cells, which in } \\
\text { turn generate type A cells. Type A cells differ- } \\
\text { entiate into olfactory bulb interneurons. }\end{array}$ & Similar changes are likely to occur \\
\hline
\end{tabular}

the time course. From an upregulation or downregulation at 24 or $48 \mathrm{hr}$, one can therefore usually assume a further increase or decrease at later time points for the vast majority of genes; however, we also identified genes that change only $96 \mathrm{hr}$ after differentiation was initiated. Thus, by comparing undifferentiated cells with cells at only one early time point of differentiation, e.g., 24 hr, not all relevant transcriptional changes can be identified.

We describe 10 major patterns (clusters) of gene expression changes in the course of neural progenitor differentiation. The highest expression changes were found for downregulated genes. Of these, cluster 9 contains strong and very early expression changes, most of which involved genes with a role in cell proliferation; however, most clusters do not correspond to single functional gene categories.

A comparison of in vitro differentiation steps with biological processes in vivo is shown in Table 2.

\section{Molecular profile of neural progenitor cells}

Because differentiated neuronal and glial cells were not investigated independently, we cannot correlate expression changes to cell types, except for the known cell type-specific genes; however, we can assign the downregulated genes to the undifferentiated neurosphere state, although spheres are also heterogeneous. This approach has been used successfully previously to identify a molecular profile of neural progenitor cells by comparing only two states (undifferentiated vs differentiated) (Geschwind et al., 2001; Easterday et al., 2003; Karsten et al., 2003). Several genes with higher expression in progenitor cells that were reported in one of these studies were also identified by us. They include the cell cycle-related genes Cyclin B1, D1, D2, Cdc2a, and PDZ-binding kinase. Other genes that decreased in expression at $24 \mathrm{hr}$ in our study and the above-mentioned studies are Fabp7, Gpi, Hmgb2, Lrrfip1, Mcm6, Olig2, Pttg1, Tnc, Racgap1, Histone H2A.Z, and Cadherin 13 (T-cadherin).

Almost no overlap exists between genes that we identified and those found by Zhou et al. (2001) and Wen et al. (2002). These groups compared undifferentiated neurosphere cells from the striatum of rat embryos with differentiated cells. Only a DNA polymerase subunit was found by us and Zhou et al. (2001) and the Siva-1 (CD27) gene (not listed in Table 1) was found by us and by Wen et al. (2002).

In addition, many of the genes that we identified have been found previously to be specific to or enriched in neural stemprogenitor cells derived from embryonic (Ivanova et al., 2002; D'Amour and Gage, 2003; Fortunel et al., 2003) or adult (Ramalho-Santos et al., 2002) tissue by comparing their microarray profiles with those of other stem cell types (Table 1).

Many of the genes downregulated during differentiation are localized to the neural stem cell compartments. Thus, they are characteristic for neural progenitor cells in vivo and their expression is maintained under in vitro conditions. We detected the CD47, PTPNS1 (SHPS-1), Pleiotrophin, and FABP7 proteins in the SVZ and RMS of adult mouse brain sections by immunostaining. Among other cell types, all of them were found to be expressed by GFAP-positive cells in this region. In addition, some of our identified genes have been reported previously to be expressed within neural germinal zones. These are Tenascin $C$ (Jankovski and Sotelo, 1996), Hb-Egf (Nakagawa et al., 1998), Nell2 (Kim et al., 2002), Transcription factor 12 (Uittenbogaard and Chiaramello, 2002), Cyclin D1, Cyclin D2 (Geschwind et al., 2001), and Lrrfip1, Hmg2b, Racgap1, Olig2, Fabp7, and Pttg1 (Karsten et al., 2003).

\section{Similarities to radial glial cells}

From our microarray data and immunostaining results we noticed that the undifferentiated neurosphere cells share certain markers with radial glial cells, namely FABP7, Tenascin C, Nestin, and Pleiotrophin. During embryonic brain development, radial glial cells appear in the ventricular zone and extend a long radial process to the pia (for review, see Parnavelas and Nadara- 
jah, 2001; Campbell and Gotz, 2002; Tamamaki, 2002). They disappear from this region during the first 2 postnatal weeks (Tramontin et al., 2003). In contrast to songbirds, radial glial cells are absent from the intact adult mammalian SVZ (Alvarez-Buylla et al., 2002). Mammalian radial glial cells transform into mature astrocytes but also give rise to neurons in vitro and in vivo (Malatesta et al., 2000; Miyata et al., 2001; Noctor et al., 2001; Tamamaki et al., 2001; Heins et al., 2002). In the adult mammalian SVZ, astrocytes serve as stem cells. These cells and radial glial cells show an overlapping but not identical expression of molecular markers. Both express Nestin and Vimentin (Doetsch et al., 1997). In contrast to primates, radial glial cells of rodents do not express GFAP, with the exception of Bergmann radial glial cells of the cerebellum (Levitt and Rakic, 1980; Choi, 1981; Rakic, 1995; Sancho-Tello et al., 1995; Hatten, 1999), whereas SVZ adult stem cells (type B cells) are GFAP positive (Doetsch et al., 1997). FABP7, Tenascin C, Pleiotrophin, RC1, RC2, and GLAST are additional proteins synthesized by radial glial cells (Malatesta et al., 2003). Tenascin C is also present in the adult SVZ and at elongated astrocytes in the RMS (Jankovski and Sotelo, 1996). This localization strongly indicates that adult neural progenitor cells synthesize Tenascin C.

It has recently been suggested that there is a continuum of a neural stem cell compartment that links radial glial cells to astrocytes, which serve as neural stem cells in the adult mammalian brain (Alvarez-Buylla et al., 2001; Doetsch, 2003; Goldman, 2003; Gotz, 2003; Tramontin et al., 2003). The expression of GFAP, Nestin, FABP7, Tenascin C, and Pleiotrophin by our neurosphere cells places them between radial glial cells and SVZ astrocytes and could be explained by a transitional state from radial glial cells to SVZ astrocytes, because they were isolated at P7. Of interest in this context is our finding of FABP7 expression by SVZ and RMS astrocytes and of Pleiotrophin expression by different cell types in the SVZ, apparently also by SVZ astrocytes, of adult mice (Fig. 7), indicating that not only radial glial cells and possibly cells in a transitional state but also neural progenitor cells in the adult brain share these markers. Although one has to interpret the presence of molecular markers with caution because they might specify a cellular state rather than lineage, our results are consistent with the proposed lineage relationship of radial glial cells and adult SVZ stem cells.

\section{Cellular interactions within the SVZ and RMS}

It is essentially unknown how the various cells in the SVZ stem cell niche and the RMS communicate through cell-cell contacts or locally secreted factors. We found that undifferentiated neurosphere cells express $H b-E g f$, and the secreted form of the respective protein stimulates neural progenitor cell proliferation and enhances neuronal survival (Kornblum et al., 1999). Hb-Egf has also been detected in several migration pathways (Caric et al., 2001). HB-EGF could therefore act as an autocrine factor on the neural progenitor cells themselves and at the same time support the survival of migrating neuroblasts. We also found that the Pleiotrophin gene is expressed by undifferentiated neurosphere cells. Moreover, Pleiotrophin appears to be expressed by different cell types, including astrocytes and neuronal cells, in the SVZ. Several features of this protein in the embryonic brain correspond well to the situation in the adult SVZ-RMS compartment. Pleiotrophin is known to stimulate the migration of embryonic neurons in vitro, and it has been localized to radial glial processes along which embryonic neurons migrate (Maeda and Noda, 1998). We conclude that Pleiotrophin is secreted by neural pro- genitor cells, which as outlined above, share similarities with radial glial cells.

Finally, we found that the transmembrane proteins PTPNS1 (SHPS-1) and CD47, which can bind each other through their extracellular domains, are both produced by undifferentiated neurosphere cells. Moreover, an enrichment of these proteins at the interface of SVZ cells and the underlying extracellular space was noticed. In addition, we localized CD47 and PTPNS1 to GFAP-positive astrocytes and neuronal cells in the SVZ and RMS. In view of the very tight cellular contacts in this brain region, a clear assignment to the membrane of specific cell types, however, must await analysis by electron microscopy. SHPS-1 and CD47 are a cell-cell communication and signal transduction system with multiple functions in immune cells (Han et al., 2000; Oldenborg et al., 2000; Seiffert et al., 2001). In the brain, SHPS-1 and CD47 are associated with synapses, and SHPS-1 (P84) has been shown to promote neurite outgrowth (Chuang and Lagenaur, 1990; Mi et al., 2000). Two aspects of the CD47-SHPS-1 system are especially interesting. First, they are involved in IGF-I receptor signaling, and we found striking expression changes of genes encoding IGF-I modulating proteins (IGFBPs), which indicate that very early in differentiation neurosphere cells are converted into an IGF-responsive state. Second, the CD47-SHPS-1 system regulates cell aggregation and migration. This function has not been described for neural cells so far, but has been described for immune and melanoma cells (Babic et al., 2000; Liu et al., 2002; Motegi et al., 2003). The reported localization in tightly associated neurosphere cells, cells migrating as chains in vitro, and in the SVZ and RMS would be compatible with a role in cell-cell/cell-matrix contact and migration. Further investigations on the CD47-SHPS-1-system are underway in a separate study.

In summary, we have provided a dataset of dynamic gene expression changes during the first $96 \mathrm{hr}$ of postnatal neural progenitor differentiation. In addition to the investigation of transcript levels, we could correlate selected proteins to the cells that produce them. Our analysis has identified many new candidate molecules and confirmed several others that likely play important roles during the maintenance, differentiation, and migration of precursors in the SVZ. For several, the functional profile in other cellular systems strongly suggests a plausible role also in the SVZ; for others we have shown an association with cell types in the SVZ. Thus, our data should serve as a basis for future analyses of the molecular and cellular dissection of SVZ function in adult neurogenesis.

\section{References}

Akai J, Storey K (2002) Expression of gamma-adducin is associated with regions of morphogenetic cell movement in the chick embryo. Mech Dev 119 [Suppl 1]:S191-S195.

Alvarez-Buylla A, Garcia-Verdugo JM, Tramontin AD (2001) A unified hypothesis on the lineage of neural stem cells. Nat Rev Neurosci 2:287-293.

Alvarez-Buylla A, Seri B, Doetsch F (2002) Identification of neural stem cells in the adult vertebrate brain. Brain Res Bull 57:751-758.

An S, Zheng Y, Bleu T (2000) Sphingosine 1-phosphate-induced cell proliferation, survival, and related signaling events mediated by $\mathrm{G}$ proteincoupled receptors Edg3 and Edg5. J Biol Chem 275:288-296.

Babic I, Schallhorn A, Lindberg FP, Jirik FR (2000) SHPS-1 induces aggregation of $\mathrm{Ba} / \mathrm{F} 3$ pro-B cells via an interaction with $\mathrm{CD} 47$. J Immunol 164:3652-3658.

Bernal J, Nunez J (1995) Thyroid hormones and brain development. Eur J Endocrinol 133:390-398.

Birgbauer E, Dinsmore JH, Winckler B, Lander AD, Solomon F (1991) Association of ezrin isoforms with the neuronal cytoskeleton. J Neurosci Res 30:232-241. 
Boudjelal M, Taneja R, Matsubara S, Bouillet P, Dolle P, Chambon P (1997) Overexpression of Stra13, a novel retinoic acid-inducible gene of the basic helix-loop-helix family, inhibits mesodermal and promotes neuronal differentiation of P19 cells. Genes Dev 11:2052-2065.

Brackertz M, Boeke J, Zhang R, Renkawitz R (2002) Two highly related p66 proteins comprise a new family of potent transcriptional repressors interacting with MBD2 and MBD3. J Biol Chem 277:40958-40966.

Brody SL, Yan XH, Wuerffel MK, Song SK, Shapiro SD (2000) Ciliogenesis and left-right axis defects in forkhead factor HFH-4-null mice. Am J Respir Cell Mol Biol 23:45-51.

Buhusi M, Midkiff BR, Gates AM, Richter M, Schachner M, Maness PF (2003) Close homolog of L1 is an enhancer of integrin-mediated cell migration. J Biol Chem 278:25024-25031.

Calaora V, Chazal G, Nielsen PJ, Rougon G, Moreau H (1996) mCD24 expression in the developing mouse brain and in zones of secondary neurogenesis in the adult. Neuroscience 73:581-594.

Campbell K, Gotz M (2002) Radial glia: multi-purpose cells for vertebrate brain development. Trends Neurosci 25:235-238.

Capela A, Temple S (2002) LeX/ssea-1 is expressed by adult mouse CNS stem cells, identifying them as nonependymal. Neuron 35:865-875.

Caric D, Raphael H, Viti J, Feathers A, Wancio D, Lillien L (2001) EGFRs mediate chemotactic migration in the developing telencephalon. Development 128:4203-4216.

Chiasson BJ, Tropepe V, Morshead CM, van der Kooy D (1999) Adult mammalian forebrain ependymal and subependymal cells demonstrate proliferative potential, but only subependymal cells have neural stem cell characteristics. J Neurosci 19:4462-4471.

Choi BH (1981) Radial glia of developing human fetal spinal cord: Golgi, immunohistochemical and electron microscopic study. Brain Res 227:249-267.

Chotteau-Lelievre A, Desbiens X, Pelczar H, Defossez PA, de Launoit Y (1997) Differential expression patterns of the PEA3 group transcription factors through murine embryonic development. Oncogene 15:937-952.

Chuang W, Lagenaur CF (1990) Central nervous system antigen P84 can serve as a substrate for neurite outgrowth. Dev Biol 137:219-232.

Clemmons DR, Maile LA (2003) Minireview: integral membrane proteins that function coordinately with the insulin-like growth factor I receptor to regulate intracellular signaling. Endocrinology 144:1664-1670.

Clevidence DE, Overdier DG, Tao W, Qian X, Pani L, Lai E, Costa RH (1993) Identification of nine tissue-specific transcription factors of the hepatocyte nuclear factor 3/forkhead DNA-binding-domain family. Proc Natl Acad Sci USA 90:3948-3952.

Crambert G, Geering K (2003) FXYD proteins: new tissue-specific regulators of the ubiquitous Na,K-ATPase. Sci STKE 2003:RE1.

D'Amour KA, Gage FH (2003) Genetic and functional differences between multipotent neural and pluripotent embryonic stem cells. Proc Natl Acad Sci USA 100 [Suppl 1G]:11866-11872.

Dean C, Scholl FG, Choih J, DeMaria S, Berger J, Isacoff E, Scheiffele P (2003) Neurexin mediates the assembly of presynaptic terminals. Nat Neurosci 6:708-716

D’Ercole AJ, Ye P, O’Kusky JR (2002) Mutant mouse models of insulin-like growth factor actions in the central nervous system. Neuropeptides 36:209-220.

Derouiche A, Frotscher M (2001) Peripheral astrocyte processes: monitoring by selective immunostaining for the actin-binding ERM proteins. Glia 36:330-341.

Deuel TF, Zhang N, Yeh HJ, Silos-Santiago I, Wang ZY (2002) Pleiotrophin: a cytokine with diverse functions and a novel signaling pathway. Arch Biochem Biophys 397:162-171.

Doetsch F (2003) A niche for adult neural stem cells. Curr Opin Genet Dev 13:543-550.

Doetsch F, Garcia-Verdugo JM, Alvarez-Buylla A (1997) Cellular composition and three-dimensional organization of the subventricular germinal zone in the adult mammalian brain. J Neurosci 17:5046-5061.

Doetsch F, Caille I, Lim DA, Garcia-Verdugo JM, Alvarez-Buylla A (1999a) Subventricular zone astrocytes are neural stem cells in the adult mammalian brain. Cell 97:703-716.

Doetsch F, Garcia-Verdugo JM, Alvarez-Buylla A (1999b) Regeneration of a germinal layer in the adult mammalian brain. Proc Natl Acad Sci USA 96:11619-11624.

Doetsch F, Petreanu L, Caille I, Garcia-Verdugo JM, Alvarez-Buylla A (2002)
EGF converts transit-amplifying neurogenic precursors in the adult brain into multipotent stem cells. Neuron 36:1021-1034.

Donato R (2003) Intracellular and extracellular roles of S100 proteins. Microsc Res Tech 60:540-551.

Easterday MC, Dougherty JD, Jackson RL, Ou J, Nakano I, Paucar AA, Roobini B, Dianati M, Irvin DK, Weissman IL, Terskikh AV, Geschwind DH, Kornblum HI (2003) Neural progenitor genes. Germinal zone expression and analysis of genetic overlap in stem cell populations. Dev Biol 264:309-322.

Eriksson PS, Perfilieva E, Bjork-Eriksson T, Alborn AM, Nordborg C, Peterson DA, Gage FH (1998) Neurogenesis in the adult human hippocampus. Nat Med 4:1313-1317.

Everett AW, Nichol KA (1990) Ezrin immunoreactivity in neuron subpopulations: cellular distribution in relation to cytoskeletal proteins in sensory neurons. J Histochem Cytochem 38:1137-1144.

Feng L, Hatten ME, Heintz N (1994) Brain lipid-binding protein (BLBP): a novel signaling system in the developing mammalian CNS. Neuron 12:895-908.

Firth SM, Baxter RC (2002) Cellular actions of the insulin-like growth factor binding proteins. Endocr Rev 23:824-854.

Forrest D, Reh TA, Rusch A (2002) Neurodevelopmental control by thyroid hormone receptors. Curr Opin Neurobiol 12:49-56.

Fortunel NO, Otu HH, Ng HH, Chen J, Mu X, Chevassut T, Li X, Joseph M, Bailey C, Hatzfeld JA, Hatzfeld A, Usta F, Vega VB, Long PM, Libermann TA, Lim B (2003) Comment on "Stemness': transcriptional profiling of embryonic and adult stem cells" and "a stem cell molecular signature." Science 302:393.

Gage FH (2000) Mammalian neural stem cells. Science 287:1433-1438.

Gaudet S, Branton D, Lue RA (2000) Characterization of PDZ-binding kinase, a mitotic kinase. Proc Natl Acad Sci USA 97:5167-5172.

Gerdes J, Schwab U, Lemke H, Stein H (1983) Production of a mouse monoclonal antibody reactive with a human nuclear antigen associated with cell proliferation. Int J Cancer 31:13-20.

Geschwind DH, Ou J, Easterday MC, Dougherty JD, Jackson RL, Chen Z, Antoine H, Terskikh A, Weissman IL, Nelson SF, Kornblum HI (2001) A genetic analysis of neural progenitor differentiation. Neuron 29:325-339.

Goldman S (2003) Glia as neural progenitor cells. Trends Neurosci 26:590-596.

Gomes ML, de Mattos DM, de Souza Freitas R, Bezerra RJ, Bernardo-Filho M (2001a) Study of the toxicological effect of mitomycin C in mice: alteration on the biodistribution of radiopharmaceuticals used for renal evaluations. Hum Exp Toxicol 20:193-197.

Gomes FC, Lima FR, Trentin AG, Moura Neto V (2001b) Thyroid hormone role in nervous system morphogenesis. Prog Brain Res 132:41-50.

Goslin K, Birgbauer E, Banker G, Solomon F (1989) The role of cytoskeleton in organizing growth cones: a microfilament-associated growth cone component depends upon microtubules for its localization. J Cell Biol 109:1621-1631.

Gotz M (2003) Glial cells generate neurons-master control within CNS regions: developmental perspectives on neural stem cells. Neuroscientist 9:379-397.

Guadano-Ferraz A, Escamez MJ, Rausell E, Bernal J (1999) Expression of type 2 iodothyronine deiodinase in hypothyroid rat brain indicates an important role of thyroid hormone in the development of specific primary sensory systems. J Neurosci 19:3430-3439.

Hack MA, Sugimori M, Lundberg C, Nakafuku M, Gotz M (2004) Regionalization and fate specification in neurospheres: the role of Olig2 and Pax6. Mol Cell Neurosci 25:664-678.

Hackett BP, Brody SL, Liang M, Zeitz ID, Bruns LA, Gitlin JD (1995) Primary structure of hepatocyte nuclear factor/forkhead homologue 4 and characterization of gene expression in the developing respiratory and reproductive epithelium. Proc Natl Acad Sci USA 92:4249-4253.

Han X, Sterling H, Chen Y, Saginario C, Brown EJ, Frazier WA, Lindberg FP, Vignery A (2000) CD47, a ligand for the macrophage fusion receptor, participates in macrophage multinucleation. J Biol Chem 275:37984-37992.

Hatten ME (1999) Central nervous system neuronal migration. Annu Rev Neurosci 22:511-539.

Heins N, Malatesta P, Cecconi F, Nakafuku M, Tucker KL, Hack MA, Chapouton P, Barde YA, Gotz M (2002) Glial cells generate neurons: the role of the transcription factor Pax6. Nat Neurosci 5:308-315.

Hillenbrand R, Molthagen M, Montag D, Schachner M (1999) The close homologue of the neural adhesion molecule L1 (CHL1): patterns of ex- 
pression and promotion of neurite outgrowth by heterophilic interactions. Eur J Neurosci 11:813-826.

Hitoshi S, Alexson T, Tropepe V, Donoviel D, Elia AJ, Nye JS, Conlon RA, Mak TW, Bernstein A, van der Kooy D (2002) Notch pathway molecules are essential for the maintenance, but not the generation, of mammalian neural stem cells. Genes Dev 16:846-858.

Hsieh J, Aimone JB, Kaspar BK, Kuwabara T, Nakashima K, Gage FH (2004) IGF-I instructs multipotent adult neural progenitor cells to become oligodendrocytes. J Cell Biol 164:111-122.

Hsueh YP, Sheng M (1999) Regulated expression and subcellular localization of syndecan heparan sulfate proteoglycans and the syndecan-binding protein CASK/LIN-2 during rat brain development. J Neurosci 19:7415-7425.

Hu QD, Ang BT, Karsak M, Hu WP, Cui XY, Duka T, Takeda Y, Chia W, Sankar N, Ng YK, Ling EA, Maciag T, Small D, Trifonova R, Kopan R, Okano H, Nakafuku M, Chiba S, Hirai H, Aster JC, et al. (2003) F3/ contactin acts as a functional ligand for Notch during oligodendrocyte maturation. Cell 115:163-175.

Huang ZY, Wu Y, Hedrick N, Gutmann DH (2003) T-cadherin-mediated cell growth regulation involves G2 phase arrest and requires p21(CIP1/ WAF1) expression. Mol Cell Biol 23:566-578.

Huber W, Von Heydebreck A, Sultmann H, Poustka A, Vingron M (2002) Variance stabilization applied to microarray data calibration and to the quantification of differential expression. Bioinformatics 18 [Suppl 1]:S96-S104.

Ivanov D, Philippova M, Tkachuk V, Erne P, Resink T (2004) Cell adhesion molecule T-cadherin regulates vascular cell adhesion, phenotype and motility. Exp Cell Res 293:207-218.

Ivanova NB, Dimos JT, Schaniel C, Hackney JA, Moore KA, Lemischka IR (2002) A stem cell molecular signature. Science 298:601-604.

Izon DJ, Aster JC, He Y, Weng A, Karnell FG, Patriub V, Xu L, Bakkour S, Rodriguez C, Allman D, Pear WS (2002) Deltex1 redirects lymphoid progenitors to the B cell lineage by antagonizing Notch1. Immunity 16:231-243.

Jacobsen L, Madsen P, Moestrup SK, Lund AH, Tommerup N, Nykjaer A, Sottrup-Jensen L, Gliemann J, Petersen CM (1996) Molecular characterization of a novel human hybrid-type receptor that binds the alpha2macroglobulin receptor-associated protein. J Biol Chem 271:31379-31383.

Jankovski A, Sotelo C (1996) Subventricular zone-olfactory bulb migratory pathway in the adult mouse: cellular composition and specificity as determined by heterochronic and heterotopic transplantation. J Comp Neurol 371:376-396.

Jauneau AC, Ischenko A, Chan P, Fontaine M (2003) Complement component anaphylatoxins upregulate chemokine expression by human astrocytes. FEBS Lett 537:17-22.

Jaworski DM, Fager N (2000) Regulation of tissue inhibitor of metalloproteinase-3 (Timp-3) mRNA expression during rat CNS development. J Neurosci Res 61:396-408.

Jin K, Mao XO, Sun Y, Xie L, Jin L, Nishi E, Klagsbrun M, Greenberg DA (2002) Heparin-binding epidermal growth factor-like growth factor: hypoxia-inducible expression in vitro and stimulation of neurogenesis in vitro and in vivo. J Neurosci 22:5365-5373.

Jin K, Sun Y, Xie L, Batteur S, Mao XO, Smelick C, Logvinova A, Greenberg DA (2003) Neurogenesis and aging: FGF-2 and HB-EGF restore neurogenesis in hippocampus and subventricular zone of aged mice. Aging Cell 2:175-183.

Johansson CB, Momma S, Clarke DL, Risling M, Lendahl U, Frisen J (1999) Identification of a neural stem cell in the adult mammalian central nervous system. Cell 96:25-34.

Jones FS, Jones PL (2000) The tenascin family of ECM glycoproteins: structure, function, and regulation during embryonic development and tissue remodeling. Dev Dyn 218:235-259.

Karsten SL, Kudo LC, Jackson R, Sabatti C, Kornblum HI, Geschwind DH (2003) Global analysis of gene expression in neural progenitors reveals specific cell-cycle, signaling, and metabolic networks. Dev Biol 261:165-182.

Kim EJ, Helfman DM (2003) Characterization of the metastasis-associated protein, S100A4. Roles of calcium binding and dimerization in cellular localization and interaction with myosin. J Biol Chem 278:30063-30073.

Kim H, Ha CM, Choi J, Choi EJ, Jeon J, Kim C, Park SK, Kang SS, Kim K, Lee BJ (2002) Ontogeny and the possible function of a novel epidermal growth factor-like repeat domain-containing protein, NELL2, in the rat brain. J Neurochem 83:1389-1400.

Kinnunen A, Kinnunen T, Kaksonen M, Nolo R, Panula P, Rauvala H (1998) $\mathrm{N}$-syndecan and HB-GAM (heparin-binding growth-associated molecule) associate with early axonal tracts in the rat brain. Eur J Neurosci 10:635-648.

Kinnunen A, Niemi M, Kinnunen T, Kaksonen M, Nolo R, Rauvala H (1999) Heparan sulphate and HB-GAM (heparin-binding growth-associated molecule) in the development of the thalamocortical pathway of rat brain. Eur J Neurosci 11:491-502.

Kishi N, Tang Z, Maeda Y, Hirai A, Mo R, Ito M, Suzuki S, Nakao K, Kinoshita T, Kadesch T, Hui C, Artavanis-Tsakonas S, Okano H, Matsuno K (2001) Murine homologs of deltex define a novel gene family involved in vertebrate Notch signaling and neurogenesis. Int J Dev Neurosci 19:21-35.

Klein ES, Simmons DM, Swanson LW, Rosenfeld MG (1993) Tissuespecific RNA splicing generates an ankyrin-like domain that affects the dimerization and DNA-binding properties of a bHLH protein. Genes Dev 7:55-71.

Kon J, Sato K, Watanabe T, Tomura H, Kuwabara A, Kimura T, Tamama K, Ishizuka T, Murata N, Kanda T, Kobayashi I, Ohta H, Ui M, Okajima F (1999) Comparison of intrinsic activities of the putative sphingosine 1-phosphate receptor subtypes to regulate several signaling pathways in their cDNA-transfected Chinese hamster ovary cells. J Biol Chem 274:23940-23947.

Kondo M, Ji L, Kamibayashi C, Tomizawa Y, Randle D, Sekido Y, Yokota J, Kashuba V, Zabarovsky E, Kuzmin I, Lerman M, Roth J, Minna JD (2001) Overexpression of candidate tumor suppressor gene FUS1 isolated from the 3 p21.3 homozygous deletion region leads to G1 arrest and growth inhibition of lung cancer cells. Oncogene 20:6258-6262.

Konig S, Moura Neto V (2002) Thyroid hormone actions on neural cells. Cell Mol Neurobiol 22:517-544.

Kornack DR, Rakic P (1999) Continuation of neurogenesis in the hippocampus of the adult macaque monkey. Proc Natl Acad Sci USA 96:5768-5773.

Kornblum HI, Zurcher SD, Werb Z, Derynck R, Seroogy KB (1999) Multiple trophic actions of heparin-binding epidermal growth factor (HBEGF) in the central nervous system. Eur J Neurosci 11:3236-3246.

Kuroda S, Oyasu M, Kawakami M, Kanayama N, Tanizawa K, Saito N, Abe T, Matsuhashi S, Ting K (1999) Biochemical characterization and expression analysis of neural thrombospondin-1-like proteins NELL1 and NELL2. Biochem Biophys Res Commun 265:79-86.

Kurtz A, Zimmer A, Schnutgen F, Bruning G, Spener F, Muller T (1994) The expression pattern of a novel gene encoding brain-fatty acid binding protein correlates with neuronal and glial cell development. Development 120:2637-2649.

Laywell ED, Rakic P, Kukekov VG, Holland EC, Steindler DA (2000) Identification of a multipotent astrocytic stem cell in the immature and adult mouse brain. Proc Natl Acad Sci USA 97:13883-13888.

Levitt P, Rakic P (1980) Immunoperoxidase localization of glial fibrillary acidic protein in radial glial cells and astrocytes of the developing rhesus monkey brain. J Comp Neurol 193:815-840.

Leyton J, Garcia-Marin L, Jensen RT, Moody TW (2002) Neurotensin causes tyrosine phosphorylation of focal adhesion kinase in lung cancer cells. Eur J Pharmacol 442:179-186.

Li YS, Milner PG, Chauhan AK, Watson MA, Hoffman RM, Kodner CM, Milbrandt J, Deuel TF (1990) Cloning and expression of a developmentally regulated protein that induces mitogenic and neurite outgrowth activity. Science 250:1690-1694.

Lim L, Zhou H, Costa RH (1997) The winged helix transcription factor HFH-4 is expressed during choroid plexus epithelial development in the mouse embryo. Proc Natl Acad Sci USA 94:3094-3099.

Lima FR, Gervais A, Colin C, Izembart M, Neto VM, Mallat M (2001) Regulation of microglial development: a novel role for thyroid hormone. J Neurosci 21:2028-2038.

Liu Y, Buhring HJ, Zen K, Burst SL, Schnell FJ, Williams IR, Parkos CA (2002) Signal regulatory protein (SIRPalpha), a cellular ligand for CD47, regulates neutrophil transmigration. J Biol Chem 277:10028-10036.

Lois C, Garcia-Verdugo JM, Alvarez-Buylla A (1996) Chain migration of neuronal precursors. Science 271:978-981.

Lu QR, Yuk D, Alberta JA, Zhu Z, Pawlitzky I, Chan J, McMahon AP, Stiles CD, Rowitch DH (2000) Sonic hedgehog-regulated oligodendrocyte 
lineage genes encoding bHLH proteins in the mammalian central nervous system. Neuron 25:317-329.

Maeda N, Noda M (1998) Involvement of receptor-like protein tyrosine phosphatase zeta/RPTPbeta and its ligand pleiotrophin/heparin-binding growth-associated molecule (HB-GAM) in neuronal migration. J Cell Biol 142:203-216.

Malatesta P, Hartfuss E, Gotz M (2000) Isolation of radial glial cells by fluorescent-activated cell sorting reveals a neuronal lineage. Development 127:5253-5263.

Malatesta P, Hack MA, Hartfuss E, Kettenmann H, Klinkert W, Kirchhoff F, Gotz M (2003) Neuronal or glial progeny: regional differences in radial glia fate. Neuron 37:751-764.

Martinez R, Gomes FC (2002) Neuritogenesis induced by thyroid hormone-treated astrocytes is mediated by epidermal growth factor/ mitogen-activated protein kinase-phosphatidylinositol 3-kinase pathways and involves modulation of extracellular matrix proteins. J Biol Chem 277:49311-49318.

Matsumoto K, Wanaka A, Takatsuji K, Muramatsu H, Muramatsu T, Tohyama M (1994) A novel family of heparin-binding growth factors, pleiotrophin and midkine, is expressed in the developing rat cerebral cortex. Brain Res Dev Brain Res 79:229-241.

Matsuno K, Eastman D, Mitsiades T, Quinn AM, Carcanciu ML, Ordentlich P, Kadesch T, Artavanis-Tsakonas S (1998) Human deltex is a conserved regulator of Notch signaling. Nat Genet 19:74-78.

Matsuoka Y, Li X, Bennett V (1998) Adducin is an in vivo substrate for protein kinase C: phosphorylation in the MARCKS-related domain inhibits activity in promoting spectrin-actin complexes and occurs in many cells, including dendritic spines of neurons. J Cell Biol 142:485-497.

McKay R (1997) Stem cells in the central nervous system. Science 276:66-71.

Menard S, Castronovo V, Tagliabue E, Sobel ME (1997) New insights into the metastasis-associated $67 \mathrm{kD}$ laminin receptor. J Cell Biochem 67:155-165.

Meyer G, Feldman EL (2002) Signaling mechanisms that regulate actinbased motility processes in the nervous system. J Neurochem 83:490-503.

Mi ZP, Jiang P, Weng WL, Lindberg FP, Narayanan V, Lagenaur CF (2000) Expression of a synapse-associated membrane protein, P84/SHPS-1, and its ligand, IAP/CD47, in mouse retina. J Comp Neurol 416:335-344.

Missler M, Sudhof TC (1998) Neurexins: three genes and 1001 products. Trends Genet 14:20-26.

Mitsiadis TA, Gayet O, Zhang N, Carroll P (2001) Expression of Deltex1 during mouse embryogenesis: comparison with Notch1, 2 and 3 expression. Mech Dev 109:399-403.

Miyata T, Kawaguchi A, Okano H, Ogawa M (2001) Asymmetric inheritance of radial glial fibers by cortical neurons. Neuron 31:727-741.

Mohan S, Baylink DJ (2002) IGF-binding proteins are multifunctional and act via IGF-dependent and -independent mechanisms. J Endocrinol 175:19-31.

Morshead CM, van der Kooy D (2003) Adult multipotential, self-renewing neurospheres in vitro are the clonal derivatives of relatively quiescent neural stem cells in vivo. Soc Neurosci Abstr 29:28.13.

Morshead CM, Reynolds BA, Craig CG, McBurney MW, Staines WA, Morassutti D, Weiss S, van der Kooy D (1994) Neural stem cells in the adult mammalian forebrain: a relatively quiescent subpopulation of subependymal cells. Neuron 13:1071-1082.

Motegi S, Okazawa H, Ohnishi H, Sato R, Kaneko Y, Kobayashi H, Tomizawa $\mathrm{K}$, Ito T, Honma N, Buhring HJ, Ishikawa O, Matozaki T (2003) Role of the CD47-SHPS-1 system in regulation of cell migration. EMBO J 22:2634-2644.

Motoi Y, Aizawa T, Haga S, Nakamura S, Namba Y, Ikeda K (1999) Neuronal localization of a novel mosaic apolipoprotein E receptor, LR11, in rat and human brain. Brain Res 833:209-215.

Muragaki Y, Timmons S, Griffith CM, Oh SP, Fadel B, Quertermous T, Olsen BR (1995) Mouse Coll8al is expressed in a tissue-specific manner as three alternative variants and is localized in basement membrane zones. Proc Natl Acad Sci USA 92:8763-8767.

Muramatsu T (2002) Midkine and pleiotrophin: two related proteins involved in development, survival, inflammation and tumorigenesis. J Biochem (Tokyo) 132:359-371.

Murphy DB, Seemann S, Wiese S, Kirschner R, Grzeschik KH, Thies U (1997) The human hepatocyte nuclear factor 3/fork head gene FKHL13: genomic structure and pattern of expression. Genomics 40:462-469.
Nakagawa T, Sasahara M, Hayase Y, Haneda M, Yasuda H, Kikkawa R, Higashiyama S, Hazama F (1998) Neuronal and glial expression of heparin-binding EGF-like growth factor in central nervous system of prenatal and early-postnatal rat. Brain Res Dev Brain Res 108:263-272.

Nataf S, Stahel PF, Davoust N, Barnum SR (1999) Complement anaphylatoxin receptors on neurons: new tricks for old receptors? Trends Neurosci 22:397-402.

Nelson BR, Matsuhashi S, Lefcort F (2002) Restricted neural epidermal growth factor-like like 2 (NELL2) expression during muscle and neuronal differentiation. Mech Dev 119 [Suppl 1]:S11-S19.

Neuman T, Keen A, Knapik E, Shain D, Ross M, Nornes HO, Zuber MX (1993) ME1 and GE1: basic helix-loop-helix transcription factors expressed at high levels in the developing nervous system and in morphogenetically active regions. Eur J Neurosci 5:311-318.

Noctor SC, Flint AC, Weissman TA, Dammerman RS, Kriegstein AR (2001) Neurons derived from radial glial cells establish radial units in neocortex. Nature 409:714-720.

Nolo R, Kaksonen M, Rauvala H (1996) Developmentally regulated neurite outgrowth response from dorsal root ganglion neurons to heparinbinding growth-associated molecule (HB-GAM) and the expression of HB-GAM in the targets of the developing dorsal root ganglion neurites. Eur J Neurosci 8:1658-1665.

Norton JD (2000) ID helix-loop-helix proteins in cell growth, differentiation and tumorigenesis. J Cell Sci 113:3897-3905.

Okamoto H, Takuwa N, Yokomizo T, Sugimoto N, Sakurada S, Shigematsu H, Takuwa Y (2000) Inhibitory regulation of Rac activation, membrane ruffling, and cell migration by the G protein-coupled sphingosine-1phosphate receptor EDG5 but not EDG1 or EDG3. Mol Cell Biol 20:9247-9261.

Oldenborg PA, Zheleznyak A, Fang YF, Lagenaur CF, Gresham HD, Lindberg FP (2000) Role of CD47 as a marker of self on red blood cells. Science 288:2051-2054.

Oyasu M, Kuroda S, Nakashita M, Fujimiya M, Kikkawa U, Saito N (2000) Immunocytochemical localization of a neuron-specific thrombospondin-1like protein, NELL2: light and electron microscopic studies in the rat brain. Brain Res Mol Brain Res 76:151-160.

Paglini G, Kunda P, Quiroga S, Kosik K, Caceres A (1998) Suppression of radixin and moesin alters growth cone morphology, motility, and process formation in primary cultured neurons. J Cell Biol 143:443-455.

Parnavelas JG, Nadarajah B (2001) Radial glial cells. Are they really glia? Neuron 31:881-884.

Peretto P, Merighi A, Fasolo A, Bonfanti L (1997) Glial tubes in the rostral migratory stream of the adult rat. Brain Res Bull 42:9-21.

Pfeiffer-Guglielmi B, Fleckenstein B, Jung G, Hamprecht B (2003) Immunocytochemical localization of glycogen phosphorylase isozymes in rat nervous tissues by using isozyme-specific antibodies. J Neurochem 85:73-81.

Rakic P (1995) Radial versus tangential migration of neuronal clones in the developing cerebral cortex. Proc Natl Acad Sci USA 92:11323-11327.

Ramalho-Santos M, Yoon S, Matsuzaki Y, Mulligan RC, Melton DA (2002) "Stemness": transcriptional profiling of embryonic and adult stem cells. Science 298:597-600.

Rapraeger AC (2001) Molecular interactions of syndecans during development. Semin Cell Dev Biol 12:107-116.

Raulo E, Chernousov MA, Carey DJ, Nolo R, Rauvala H (1994) Isolation of a neuronal cell surface receptor of heparin binding growth-associated molecule (HB-GAM). Identification as N-syndecan (syndecan-3). J Biol Chem 269:12999-13004.

Rauvala H, Vanhala A, Castren E, Nolo R, Raulo E, Merenmies J, Panula P (1994) Expression of HB-GAM (heparin-binding growth-associated molecules) in the pathways of developing axonal processes in vivo and neurite outgrowth in vitro induced by HB-GAM. Brain Res Dev Brain Res 79:157-176.

Reynolds BA, Weiss S (1992) Generation of neurons and astrocytes from isolated cells of the adult mammalian central nervous system. Science 255:1707-1710.

Richards LJ, Kilpatrick TJ, Bartlett PF (1992) De novo generation of neuronal cells from the adult mouse brain. Proc Natl Acad Sci USA 89:8591-8595.

Ronfani L, Ferraguti M, Croci L, Ovitt CE, Scholer HR, Consalez GG, Bianchi ME (2001) Reduced fertility and spermatogenesis defects in mice lacking chromosomal protein Hmgb2. Development 128:1265-1273. 
Saarela J, Rehn M, Oikarinen A, Autio-Harmainen H, Pihlajaniemi T (1998) The short and long forms of type XVIII collagen show clear tissue specificities in their expression and location in basement membrane zones in humans. Am J Pathol 153:611-626.

Sabatti C, Karsten SL, Geschwind DH (2002) Thresholding rules for recovering a sparse signal from microarray experiments. Math Biosci 176:17-34.

Sanai N, Tramontin AD, Quinones-Hinojosa A, Barbaro NM, Gupta N, Kunwar S, Lawton MT, McDermott MW, Parsa AT, Manuel-Garcia Verdugo J, Berger MS, Alvarez-Buylla A (2004) Unique astrocyte ribbon in adult human brain contains neural stem cells but lacks chain migration. Nature 427:740-744.

Sancho-Tello M, Valles S, Montoliu C, Renau-Piqueras J, Guerri C (1995) Developmental pattern of GFAP and vimentin gene expression in rat brain and in radial glial cultures. Glia 15:157-166.

Sapiro R, Kostetskii I, Olds-Clarke P, Gerton GL, Radice GL, Strauss IJ (2002) Male infertility, impaired sperm motility, and hydrocephalus in mice deficient in sperm-associated antigen 6. Mol Cell Biol 22:6298-6305.

Seiffert M, Brossart P, Cant C, Cella M, Colonna M, Brugger W, Kanz L, Ullrich A, Buhring HJ (2001) Signal-regulatory protein alpha (SIRPalpha) but not SIRPbeta is involved in T-cell activation, binds to CD47 with high affinity, and is expressed on immature CD34(+)CD38(-) hematopoietic cells. Blood 97:2741-2749.

Sertie AL, Sossi V, Camargo AA, Zatz M, Brahe C, Passos-Bueno MR (2000) Collagen XVIII, containing an endogenous inhibitor of angiogenesis and tumor growth, plays a critical role in the maintenance of retinal structure and in neural tube closure (Knobloch syndrome). Hum Mol Genet 9:2051-2058.

Sestan N, Artavanis-Tsakonas S, Rakic P (1999) Contact-dependent inhibition of cortical neurite growth mediated by notch signaling. Science 286:741-746.

Silos-Santiago I, Yeh HJ, Gurrieri MA, Guillerman RP, Li YS, Wolf J, Snider W, Deuel TF (1996) Localization of pleiotrophin and its mRNA in subpopulations of neurons and their corresponding axonal tracts suggests important roles in neural-glial interactions during development and in maturity. J Neurobiol 31:283-296.

Small JV, Stradal T, Vignal E, Rottner K (2002) The lamellipodium: where motility begins. Trends Cell Biol 12:112-120.

Steiner R, Ever L, Don J (1999) MEIG1 localizes to the nucleus and binds to meiotic chromosomes of spermatocytes as they initiate meiosis. Dev Biol 216:635-645.

St. Pierre B, Flock G, Zacksenhaus E, Egan SE (2002) Stra13 homodimers repress transcription through class B E-box elements. J Biol Chem 277:46544-46551.

Sun H, Taneja R (2000) Stra13 expression is associated with growth arrest and represses transcription through histone deacetylase (HDAC)dependent and HDAC-independent mechanisms. Proc Natl Acad Sci USA 97:4058-4063.

Sun YJ, Chou CC, Chen WS, Wu RT, Meng M, Hsiao CD (1999) The crystal structure of a multifunctional protein: phosphoglucose isomerase/autocrine motility factor/neuroleukin. Proc Natl Acad Sci USA 96:5412-5417.

Suslov ON, Kukekov VG, Ignatova TN, Steindler DA (2002) Neural stem cell heterogeneity demonstrated by molecular phenotyping of clonal neurospheres. Proc Natl Acad Sci USA 99:14506-14511.

Takahashi M, Yamagata M, Noda M (1999) Specific expression of ezrin, a cytoskeletal-membrane linker protein, in a subset of chick retinotectal and sensory projections. Eur J Neurosci 11:545-558.

Take M, Tsutsui J, Obama H, Ozawa M, Nakayama T, Maruyama I, Arima T, Muramatsu T (1994) Identification of nucleolin as a binding protein for midkine (MK) and heparin-binding growth associated molecule (HBGAM). J Biochem (Tokyo) 116:1063-1068.

Takebayashi H, Yoshida S, Sugimori M, Kosako H, Kominami R, Nakafuku M, Nabeshima Y (2000) Dynamic expression of basic helix-loop-helix Olig family members: implication of Olig2 in neuron and oligodendrocyte differentiation and identification of a new member, Olig3. Mech Dev 99:143-148.

Takeuchi T, Ohtsuki Y (2001) Recent progress in T-cadherin (CDH13, H-cadherin) research. Histol Histopathol 16:1287-1293.

Takeuchi T, Misaki A, Liang SB, Tachibana A, Hayashi N, Sonobe H, Ohtsuki Y (2000) Expression of T-cadherin (CDH13, H-Cadherin) in human brain and its characteristics as a negative growth regulator of epidermal growth factor in neuroblastoma cells. J Neurochem 74:1489-1497.

Tamamaki N (2002) Radial glias and radial fibers: what is the function of radial fibers? Anat Sci Int 77:2-11.
Tamamaki N, Nakamura K, Okamoto K, Kaneko T (2001) Radial glia is a progenitor of neocortical neurons in the developing cerebral cortex. Neurosci Res 41:51-60.

Tanigaki K, Nogaki F, Takahashi J, Tashiro K, Kurooka H, Honjo T (2001) Notch1 and Notch3 instructively restrict bFGF-responsive multipotent neural progenitor cells to an astroglial fate. Neuron 29:45-55.

Tekki-Kessaris N, Woodruff R, Hall AC, Gaffield W, Kimura S, Stiles CD, Rowitch DH, Richardson WD (2001) Hedgehog-dependent oligodendrocyte lineage specification in the telencephalon. Development 128:2545-2554.

Temple S (2001) The development of neural stem cells. Nature 414:112-117.

Thomas A, Gasque P, Vaudry D, Gonzalez B, Fontaine M (2000) Expression of a complete and functional complement system by human neuronal cells in vitro. Int Immunol 12:1015-1023.

Tramontin AD, Garcia-Verdugo JM, Lim DA, Alvarez-Buylla A (2003) Postnatal development of radial glia and the ventricular zone (VZ): a continuum of the neural stem cell compartment. Cereb Cortex 13:580-587.

Tyler-McMahon BM, Boules M, Richelson E (2000) Neurotensin: peptide for the next millennium. Regul Pept 93:125-136.

Uittenbogaard M, Chiaramello A (2002) Expression of the bHLH transcription factor Tcf12 (ME1) gene is linked to the expansion of precursor cell populations during neurogenesis. Gene Expr Patterns 1:115-121.

Verreault A, Kaufman PD, Kobayashi R, Stillman B (1996) Nucleosome assembly by a complex of CAF-1 and acetylated histones $\mathrm{H} 3 / \mathrm{H} 4$. Cell 87:95-104.

Vuletic S, Jin LW, Marcovina SM, Peskind ER, Moller T, Albers JJ (2003) Widespread distribution of PLTP in human CNS: evidence for PLTP synthesis by glia and neurons, and increased levels in Alzheimer's disease. J Lipid Res 44:1113-1123.

Wang F, Van Brocklyn JR, Hobson JP, Movafagh S, Zukowska-Grojec Z, Milstien S, Spiegel S (1999) Sphingosine 1-phosphate stimulates cell migration through a G(i)-coupled cell surface receptor. Potential involvement in angiogenesis. J Biol Chem 274:35343-35350.

Wen T, Gu P, Minning TA, Wu Q, Liu M, Chen F, Liu H, Huang H (2002) Microarray analysis of neural stem cell differentiation in the striatum of the fetal rat. Cell Mol Neurobiol 22:407-416.

Wewetzer K, Rauvala H, Unsicker K (1995) Immunocytochemical localization of the heparin-binding growth-associated molecule (HB-GAM) in the developing and adult rat cerebellar cortex. Brain Res 693:31-38.

Wichterle H, Garcia-Verdugo JM, Alvarez-Buylla A (1997) Direct evidence for homotypic, glia-independent neuronal migration. Neuron 18:779-791.

Winkler S, Stahl RC, Carey DJ, Bansal R (2002) Syndecan-3 and perlecan are differentially expressed by progenitors and mature oligodendrocytes and accumulate in the extracellular matrix. J Neurosci Res 69:477-487.

Yamamoto S, Nagao M, Sugimori M, Kosako H, Nakatomi H, Yamamoto N, Takebayashi H, Nabeshima Y, Kitamura T, Weinmaster G, Nakamura K, Nakafuku M (2001) Transcription factor expression and Notchdependent regulation of neural progenitors in the adult rat spinal cord. J Neurosci 21:9814-9823.

Yamazaki F, Nagatsuka Y, Shirakawa H, Yoshida M (1995) Repression of cell cycle progression by antisense HMG2 RNA. Biochem Biophys Res Commun 210:1045-1051.

Yeh HJ, He YY, Xu J, Hsu CY, Deuel TF (1998) Upregulation of pleiotrophin gene expression in developing microvasculature, macrophages, and astrocytes after acute ischemic brain injury. J Neurosci 18:3699-3707.

Yu JX, Bradt BM, Cooper NR (2002) Constitutive expression of proinflammatory complement components by subsets of neurons in the central nervous system. J Neuroimmunol 123:91-101.

Zhang Y, Flejter WL, Barcroft CL, Riviere M, Szpirer J, Szpirer C, Bina M (1995) Localization of the human HTF4 transcription factors 4 gene (TCF12) to chromosome 15q21. Cytogenet Cell Genet 68:235-238.

Zhou FC, Duguid JR, Edenberg HJ, McClintick J, Young P, Nelson P (2001) DNA microarray analysis of differential gene expression of 6-year-old rat neural striatal progenitor cells during early differentiation. Restor Neurol Neurosci 18:95-104.

Zhou Q, Wang S, Anderson DJ (2000) Identification of a novel family of oligodendrocyte lineage-specific basic helix-loop-helix transcription factors. Neuron 25:331-343. 